Published in final edited form as:

Biochemistry. 2018 February 13; 57(6): 963-977. doi:10.1021/acs.biochem.7b01137.

\title{
Structural, Biochemical, and Evolutionary Characterizations of Glyoxylate/Hydroxypyruvate Reductases Show Their Division into Two Distinct Subfamilies
}

\author{
Jan Kutner ${ }^{\dagger, \ddagger, \nabla}$, Ivan G. Shabalin ${ }^{\dagger, \nabla}$, Dorota Matelska ${ }^{\dagger, \S, \nabla}$, Katarzyna B. Handing $^{\dagger}$, Olga

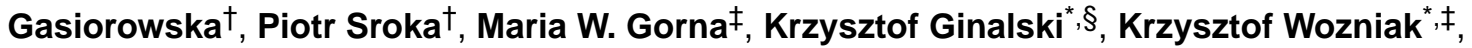 \\ and Wladek Minor ${ }^{*},+, \|$
}

tDepartment of Molecular Physiology and Biological Physics, University of Virginia, 1340 Jefferson Park Avenue, Charlottesville, Virginia 22908, United States ‡Laboratory for Structural and Biochemical Research, Biological and Chemical Research Centre, Department of Chemistry, University of Warsaw, 101 Zwirki i Wigury, 02-089 Warsaw, Poland §Laboratory of Bioinformatics and Systems Biology, Centre of New Technologies, University of Warsaw, 93 Zwirki i Wigury, 02-089 Warsaw, Poland "Department of Chemistry, University of Warsaw, 1 Ludwika Pasteura, 02-093 Warsaw, Poland

\section{Abstract \\ The D-2-hydroxyacid dehydrogenase (2HADH) family illustrates a complex evolutionary history with multiple lateral gene transfers and gene duplications and losses. As a result, the exact functional annotation of individual members can be extrapolated to a very limited extent. Here, we revise the previous simplified view on the classification of the $2 \mathrm{HADH}$ family; specifically, we show that the previously delineated glyoxylate/hydroxypyruvate reductase (GHPR) subfamily consists of two evolutionary separated GHRA and GHRB subfamilies. We compare two representatives of these subfamilies from Sinorhizobium meliloti (SmGhrA and SmGhrB), employing a combination of biochemical, structural, and bioinformatics approaches. Our kinetic}

\footnotetext{
*Corresponding Authors: kginal@cent.uw.edu.pl (K.G.)., kwozniak@chem.uw.edu.pl (K.W.)., wladek@iwonka.med.virginia.edu. Phone: (434) 243-6865. Fax: (434) 243-2981 (W.M.).

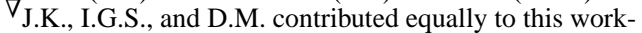

Author Contributions

Conceptualization: I.G.S., K.G., K.W., and W.M. Methodology: I.G.S., J.K., D.M., K.B.H., and O.G. Experiments: J.K., I.G.S., D.M., K.B.H., O.G., and P.S. Data analysis and interpretation: I.G.S., J.K., D.M., and W.M. Writing the original draft: J.K., I.G.S., and D.M. Review and editing: I.G.S., D.M., M.W.G., K.G., K.W., and W.M. Visualization: I.G.S., J.K., and D.M. Supervision: M.W.G., K.G., K.W., and W.M. Funding acquisition: M.W.G., K.G., K.W., and W.M. All authors read and approved the final manuscript. J.K., I.G.S., and D.M. contributed equally to this work.

The authors declare no competing financial interest.

Supporting Information

The Supporting Information is available free of charge on the ACS Publications website at DOI: 10.1021/acs.biochem.7b01137. Steady-state kinetic plots for substrates and NADPH (Figures S1 and S2). Comparison of the protein domains and their structural changes upon cofactor binding (Figures S3 and S4). Multiple sequence alignment of representative sequences of the GHRA and GHRB subfamilies (Figure S5). Genomic context of SmGhrA and SmGhrB (Figure S6). Key resources used in this study (Table S1). Results of the protein thermal shift assay (Table S2). Results of the activity screening for various substrates with NADPH as a cofactor (Tables S3 and S4) (PDF)

Accession Codes

UniProt accession IDs: Q92T34 (SmGhrA, SMc02828), Q92LZ4 (SmGhrB, SMc04462). SmGhrA PDB IDs: 4weq, 4z0p, 5unn. SmGhrB PDB IDs: 5v7n, 5v7g, 5v6q, 5j23, 5uog, 5v72.
} 
results show that both enzymes reduce several 2-ketocarboxylic acids with overlapping, but not equivalent, substrate preferences. SmGhrA and SmGhrB show highest activity with glyoxylate and hydroxypyruvate, respectively; in addition, only SmGhrB reduces 2-keto-D-gluconate, and only SmGhrA reduces pyruvate (with low efficiency). We present nine crystal structures of both enzymes in apo forms and in complexes with cofactors and substrates/substrate analogues. In particular, we determined a crystal structure of SmGhrB with 2-keto-D-gluconate, which is the biggest substrate cocrystallized with a $2 \mathrm{HADH}$ member. The structures reveal significant differences between SmGhrA and SmGhrB, both in the overall structure and within the substratebinding pocket, offering insight into the molecular basis for the observed substrate preferences and subfamily differences. In addition, we provide an overview of all GHRA and GHRB structures complexed with a ligand in the active site.

\section{Graphical Abstract}

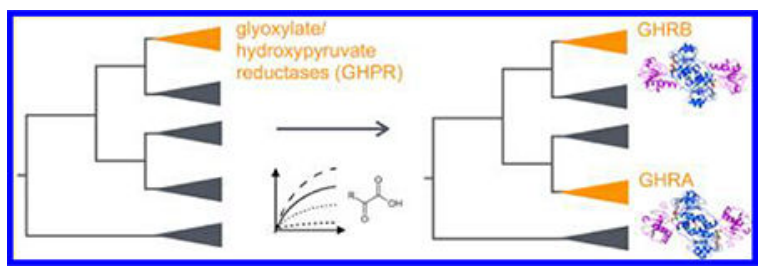

D-2-Hydroxyacid dehydrogenases (2HADHs) catalyze the reversible $\mathrm{NAD}(\mathrm{P}) \mathrm{H}$-dependent stereospecific reduction of 2-ketocarboxylic acids to the corresponding (R)-2-hydroxycarboxylic acids (Figure 1). Under physiological conditions, these enzymes preferentially catalyze the reaction in one direction using either $\mathrm{NAD}(\mathrm{P}) \mathrm{H}$ or $\mathrm{NAD}(\mathrm{P})^{+}$as a cofactor. Due to the diversity of the accepted substrates, $2 \mathrm{HADHs}$ are involved in various cellular processes. For example, vancomycin resistance protein $\mathrm{H}$ is associated with antibiotic resistance, ${ }^{1}$ phosphonate dehydrogenase is involved in the utilization of phosphite as an exogenous phosphorus source, ${ }^{2}$ D-lactate dehydrogenase catalyzes the last step of anaerobic glycolysis, ${ }^{3}$ and plant hydroxypyruvate dehydrogenases are involved in the photorespiratory cycle. ${ }^{4}$ Human $2 \mathrm{HADH}$ enzymes play an important role in metabolic pathways; a mutation in the human gene encoding glyoxylate reductase/hydroxypyruvate reductase (GRHPR) is a genetic basis for primary hyperoxaluria type II, a rare inherited disorder of glyoxylate metabolism. ${ }^{5}$

2HADHs have a number of practical applications beyond their multiple cellular functions. Enzymatic reduction by $2 \mathrm{HADHs}$ produces optically active (R)-2-hydroxycarboxylic acids with exceptionally high stereoselectivity, and the optically pure products have potential for use as "green" synthons and precursors for chiral compounds in pharmaceutical and biotechnology industrial applications. ${ }^{6-8}$ Therefore, obtaining in-depth insights into the substrate specificities, catalytic kinetics, and molecular mechanism of these enzymes is of great interest.

Prior efforts have been made to systematically classify $2 \mathrm{HADHs}$ and their characteristics. On the basis of sequence similarity, it was proposed almost three decades ago that 2HADHs constitute a protein family distinct from the L-specific dehydrogenases. ${ }^{9}$ Further 
biochemical studies have characterized more members of this family, which resulted in initial attempts to divide them into evolutionarily related subfamilies sharing similar substrate specificity. ${ }^{10,11}$ The proposed division does not, however, fully explain differences in substrate specificity and cofactor preference for closely related members within the same subfamily.

The most striking examples are found in the previously designated glyoxylate/ hydroxypyruvate reductase (GHPR) subfamily. ${ }^{10}$ GHPR comprises both reductases and dehydrogenases with relatively broad substrate specificities, spanning all three domains of life. In the classification by Fauvart et al., ${ }^{10}$ the subfamily included yeast D-mandelate dehydrogenase, ${ }^{12}$ human and archaeal glyoxylate/hydroxypyruvate reductases, ${ }^{13}$ bacterial phosphonate dehydrogenases, ${ }^{14}$ plant and fungal hydroxyphenylpyruvate reductases,,${ }^{11,15}$ and bacterial enzymes that reduce a broad range of substrates. ${ }^{10,16}$ In addition to the direction of the reaction and accepted substrates, the cofactor preferences also differ among the GHPR members. For example, GHPR from Escherichia coli (EcGhrA) reduces glyoxylate and hydroxypyruvate, preferentially using NADPH as a cofactor, ${ }^{16}$ yet its homologue from Rhizobium etli, ReGxrA, was reported to reduce the same substrates but with only NADH as the cofactor. ${ }^{10}$ These differences suggest that the functional annotation cannot be extrapolated even within the same subfamily. Although crystal structures for 17 GHPRs are reported in the PDB, most of them are without the cofactor and/or substrate bound, ${ }^{13,17-19}$ leaving the underlying substrate and cofactor discrimination mechanisms elusive.

To revise the simplified view on the previously delineated GHPR family, we chose two enzymes from Sinorhizobium meliloti 1021, an a-proteobacterium whose genome encodes nine GHPR members, none of which have been studied to date. S. meliloti is a free-living soil Gram-negative bacterium, capable of nitrogen fixation and symbioses with leguminous plants, thus playing a vital role in agriculture. ${ }^{20,21}$

In this article, we present a phylogenetic analysis that suggests a division of GHPRs into two distinct subfamilies. In an attempt to understand the functions of and the differences between the two novel subfamilies, we used biochemical, structural, and bioinformatics approaches to comparatively characterize a representative enzyme from each of the subfamilies from $\mathrm{S}$. meliloti.

\section{MATERIALS AND METHODS}

\section{Reagents and Software Used.}

All reagents used in this work with the respective commercial sources and catalog numbers, as well as all software with RRID identifiers, are listed in Table S1.

\section{Phylogenetic Analysis.}

Sequences of proteins assigned to the " $\mathrm{D}$-isomer specific 2-hydroxyacid dehydrogenase family" confirmed by biochemical tests were collected from UniProt. ${ }^{22}$ To extend this initial set, these collected sequences were used as queries in BLAST searches in selected proteomes in UniProt (Homo sapiens, Mus musculus, Saccharomyces cerevisiae, 
Escherichia coli, Agrobacterium radiobacter, Cyanidioschyzon merolae, Arabidopsis thaliana, Solanum lycopersicum, Zea mays, Bartonella grahamii, Brucella suis, Medicago truncatula, Plasmodium falciparum, Pyrococcus furiosus, Rhizobium etli, Rhizobium grahamii, Sinorhizobium americani, Sinorhizobium meliloti, Rhizobium fredii, and Xanthobacter autotrophicus). Hits with an E-value $<10^{-20}$ were included in the final set. Sequence alignment for the region encompassing both catalytic and substrate-binding domains was generated using MAFFT $7^{23}$ with the "linsi" option. Poorly aligned regions (with more than $20 \%$ gaps) were removed with trimAl 1.4. ${ }^{24}$ The maximum-likelihood tree was generated with FastTree2 ${ }^{25}$ (JTT + CAT model and Shimodaira-Hasegawa test for estimation of support values) and visualized with Archaeopteryx. ${ }^{26}$

In order to independently evaluate the consistency of the obtained tree topology, alternative trees were built and compared in the context of the GHRA and GHRB separation as follows: (a) based on the alignment prior to the trimming, (b) based on the alignment with columns containing more than $80 \%$ of gaps removed, (c) based on the alignment of the catalytic domain only (corresponding to positions 3-97 and 287-319 in SmGhrA), and (d) using the WAG + CAT model. The alternative trees showed similar topologies with clear separation between the GHRA and GHRB clades.

\section{Protein Expression and Purification.}

The genes encoding SmGhrA (SMc02828) and SmGhrB (SMc04462) were cloned into the pSGC-His expression vector by the New York Structural Genomics Research Consortium (NYSGRC targets 011884 and 012132, respectively). The E. coli BL21-CodonPlus (DE3)RIPL cells, transformed with the pSGC-His expression vector coding the protein of interest, were grown at $37^{\circ} \mathrm{C}$ in Luria Broth expression media. After the culture had reached an $\mathrm{OD}_{600}$ of $0.6-1.0$, the temperature was decreased to $16{ }^{\circ} \mathrm{C}$, protein expression was induced with $0.5 \mathrm{mM}$ IPTG, and cell growth continued for 18 additional $\mathrm{h}$. Cells were harvested by centrifugation at $35000 \mathrm{rpm}$ at $4{ }^{\circ} \mathrm{C}$ for $40 \mathrm{~min}$ (JA-10, Beckman Coulter), and pellets were stored at $-80{ }^{\circ} \mathrm{C}$ for further use. Pellets were thawed on ice and resuspended in buffer A [20 mM HEPES (pH 7.5), $500 \mathrm{mM} \mathrm{NaCl}, 15 \mathrm{mM} \mathrm{NaN}_{3}, 0.5 \mathrm{mM}$ TCEP, $10 \%$ glycerol, and 5 $\mathrm{mM}$ imidazole] with freshly added 250 units of benzonase endonuclease and a tablet of protease inhibitor cocktail. The pellets were disrupted by passing the cell suspension three times through a homogenizer at 15 000-17 000 psi (EmulsiFlex-C3, Avestin Inc.). Cell lysates were centrifuged at $35000 \mathrm{rpm}\left(45-\mathrm{Ti}\right.$, Beckman Coulter) at $4{ }^{\circ} \mathrm{C}$ for $40 \mathrm{~min}$.

The supernatants were loaded onto a gravity chromatography column containing $5 \mathrm{~mL}$ of Ni-NTA resin calibrated with buffer A and then washed with buffer A supplemented with 20 $\mathrm{mM}$ imidazole. Afterward, the proteins were eluted with buffer $\mathrm{A}$, with the imidazole concentration increased to $350 \mathrm{mM}$. The eluted proteins were further purified by sizeexclusion chromatography (ÄKTA FPLC with a Hi-Load 16/600 SuperdexTM 200 pg column, GE Healthcare) and eluted with crystallization buffer B [20 mM HEPES (pH 7.5), $150 \mathrm{mM} \mathrm{NaCl}, 10 \%$ glycerol, $15 \mathrm{mM} \mathrm{NaN}_{3}$, and $0.5 \mathrm{mM} \mathrm{TCEP].} \mathrm{Protein} \mathrm{purity} \mathrm{in} \mathrm{the}$ resulting fractions was confirmed by SDS-PAGE. The combined fractions containing SmGhrA or SmGhrB protein were concentrated (10 kDa Amicon Ultra-15 Centrifugal Filter Units, EMD Millipore) to 11.7 and $13.2 \mathrm{mg} / \mathrm{mL}$, respectively, and stored in buffer B. 
For the activity assays only, the His-tag was removed by a 5 -fold addition of $0.2 \mathrm{mg} / \mathrm{mL}$ rTEV protease to the samples eluted from the affinity column. The rTEV cleavage was performed at $16{ }^{\circ} \mathrm{C}$ overnight and confirmed by SDS-PAGE. The protease reaction products were passed through a second Ni-NTA column pre-equilibrated with buffer A. The flowthrough from the second Ni-NTA column was applied on the size-exclusion column connected to the ÄKTA FPLC system, eluted with buffer B, and concentrated to $1 \mathrm{mg} / \mathrm{mL}$.

\section{Protein Thermal Shift Assay.}

The thermal stability of proteins was measured with RT-PCR (C1000, Bio-Rad) in a 96-well PCR plate (Bio-Rad). Each well contained $12 \mu \mathrm{L}$ of $20 \times$ SYPRO Orange dye in buffer B and $12 \mu \mathrm{L}$ of $0.2 \mathrm{mg} / \mathrm{mL}$ protein, optionally supplemented with $10 \mathrm{mM}$ cofactor and/or $10 \mathrm{mM}$ ligand of interest. The used method consisted of three steps: (i) sample preincubation for 5 min at $20^{\circ} \mathrm{C}$, (ii) temperature increase by $0.5^{\circ} \mathrm{C}$ from 20 to $80^{\circ} \mathrm{C}$ within the total time of 30 min, and (iii) temperature decrease to $4{ }^{\circ} \mathrm{C}$. The melting temperatures, as determined by the Bio-Rad software, are presented in Table S2.

\section{Substrate Screening and Cofactor Preference.}

The enzyme mixed with NADPH/NADP ${ }^{+}$was incubated in a 96-well half area clear polystyrene plate (Corning) for 10 min prior to adding $20 \mu \mathrm{L}$ of a substrate to initiate the reaction. The final assay mixture contained $0.01 \mu \mathrm{g} / \mu \mathrm{L}$ SmGhrA or $0.004 \mu \mathrm{g} / \mu \mathrm{L}$ SmGhrB protein, $0.4 \mathrm{mM} \mathrm{NADPH} / \mathrm{NADP}^{+}$(saturating concentration), and a substrate at varying concentrations (Tables S3 and S4) in a final volume of $120 \mu \mathrm{L}$ of kinetic buffer $(150 \mathrm{mM}$ $\mathrm{NaCl}, 150 \mathrm{mM}$ Tris- $\mathrm{HCl} \mathrm{pH} \mathrm{7.5)} \mathrm{at} 25^{\circ} \mathrm{C}$. The reaction was monitored using the change of the absorbance of NADPH at $340 \mathrm{~nm}$. The absorbance measurements were carried out in a PHERAstar FS (BMG LABTECH Omega) or an Infinite M200 PRO (Tecan) microplate reader equipped with UV absorbance spectrophotometer at $340 \mathrm{~nm}$. The reaction was measured for $750 \mathrm{~s}$ with the absorption reading every $25 \mathrm{~s}$. The results are presented in Tables S3 and S4. The preference toward NADH or NADPH was tested in the same manner using one of the most prominent substrates for both enzymes, hydroxypyruvate, at a saturating concentration $(66.7 \mathrm{mM})$ and a cofactor at $0.4 \mathrm{mM}$ concentration.

\section{Steady-State Kinetics.}

The kinetic parameters for chosen substrates were obtained by recording the initial reaction velocity at varying concentration of a substrate while keeping the NADPH at a saturating concentration $0.4 \mathrm{mM}$ (Figure S1). Enzyme $(100 \mu \mathrm{L})$ mixed with NADPH was incubated in a 96-well half area clear polystyrene plate (Corning) in filtered and degassed kinetic buffer $(150 \mathrm{mM} \mathrm{NaCl}, 150 \mathrm{mM}$ Tris- $\mathrm{HCl} \mathrm{pH} 7.5)$ at $25{ }^{\circ} \mathrm{C}$ for $10 \mathrm{~min}$. To initiate the reaction, 20 $\mu \mathrm{L}$ of the respective substrate stock in the kinetic buffer was added. The final concertation of the enzyme was $0.01 \mu \mathrm{g} / \mu \mathrm{L}$ for SmGhrA and $0.004 \mu \mathrm{g} / \mu \mathrm{L}$ for SmGhrB. The absorbance was measured at $340 \mathrm{~nm}$ every $25 \mathrm{~s}$ for $750 \mathrm{~s}$ in total. Each measurement was performed in triplicate. The initial reaction velocities were fitted by the nonlinear least-squares method to both (a) the Michaelis-Menten equation $\mathrm{v}=\mathrm{V}_{\max } \times \mathrm{s} /\left(\mathrm{K}_{\mathrm{m}}+\mathrm{s}\right)$, where $\mathrm{v}$ is the reaction velocity, $\mathrm{V}_{\max }$ is maximum reaction velocity, $\mathrm{s}$ is substrate concentration, and $\mathrm{K}_{\mathrm{m}}$ is the Michaelis constant, and (b) the Hill equation $\mathrm{v}=\mathrm{V}_{\max } \times \mathrm{s}^{\mathrm{n}} /\left(\mathrm{K}_{0} 5^{\mathrm{n}}+\mathrm{s}^{\mathrm{n}}\right)$, where $\mathrm{n}$ is the Hill coefficient. Because $\mathrm{K}_{\mathrm{m}}$ is a special case of $\mathrm{K}_{0}(\mathrm{n}=1), \mathrm{K}_{\mathrm{m}}$ and $\mathrm{K}_{0.5}$ are generally 
expressed as $\mathrm{K}_{0.5}$ throughout the article. The obtained fittings were compared with the F-test (with the null hypothesis that the simpler Michaelis-Menten model is correct), using a cutoff of $\mathrm{p}=0.01$. The kinetic parameters, calculated using Prism software (GraphPad), are listed in Table 1. The kinetic parameters for NADPH were determined in the same manner with hydroxypyruvate at a saturating concentration $(66.7 \mathrm{mM})$ and varying concentrations of NADPH (Figure S2, Table 1). The activity with NADH was too low to determine the kinetic parameters.

\section{Protein Crystallization and Data Collection.}

All complexes of SmGhrA and SmGhrB with ligands and the apo forms were crystallized with the sitting-drop vapor-diffusion method using the recombinant protein preparations with Histag present. $100 \mathrm{mM}$ NADPH tetrasodium salt and $\mathrm{NADP}^{+}$disodium salt were prepared in $100 \mathrm{mM}$ HEPES buffer at $\mathrm{pH}$ 7.0. The $1 \mathrm{M}$ solutions of oxalic acid, glycolic acid, and 2-keto-D-gluconic acid were prepared in the same buffer. After dissolution, the $\mathrm{pH}$ of the oxalic acid and 2-keto-D-gluconic acid solutions was adjusted to 7.0 by the addition of sodium hydroxide. If applicable, the respective ligand stock solution(s) was added to the protein, and the resulting mix was incubated for $30 \mathrm{~min}$ at $16{ }^{\circ} \mathrm{C}$. Subsequently, the protein - ligand solution was supplemented with either (a) $1 / 40(\mathrm{v} / \mathrm{v})$ of $2 \mathrm{mg} / \mathrm{mL}$ chymotrypsin solution to perform limited proteolysis or (b) $1 / 15(\mathrm{v} / \mathrm{v})$ of $1 \mathrm{mg} / \mathrm{mL}$ rTEV solution to cleave the His-tag and incubated for $1 \mathrm{~h}$ at $16^{\circ} \mathrm{C}$. The crystallization experiments were set up using a Mosquito crystallization robot (TTP Labtech). $0.2 \mu \mathrm{L}$ of the protein solution was mixed with $0.2 \mu \mathrm{L}$ of the crystallization screen solution and equilibrated against $1.5 \mathrm{M} \mathrm{NaCl}$ in 3drop, 96-well crystallization plates (Hampton Research). The details of protein preparation and crystallization are summarized in Tables 2 and 3.

Crystals suitable for X-ray experiments were harvested and cryoprotected using one of the following approaches: (1) dipping in the precipitant mix supplemented with $25 \%$ glycerol or $20 \%$ ethylene glycol, (2) bathing in paratone- $\mathrm{N}$ oil for 2-3 min, (3) drying for 5-15 min over $1 \mathrm{M} \mathrm{NaCl}$ solution in a closed vial, or (4) drying by waving the harvested crystal in the air for $1 \mathrm{~min}$. Subsequently, the crystals were flash-cooled in liquid nitrogen. Diffraction data were collected from single crystals at $100 \mathrm{~K}$ at the LS-CAT 21-ID-G or SBC-CAT 19ID beamline at the Advanced Photon Source, Argonne National Laboratory (Argonne, IL). The details of cryoprotection and data collection are summarized in Tables 2 and 3.

For some complexes, both limited proteolysis with chymotrypsin and His-tag removal with rTEV resulted in crystals that diffracted to $\sim 2 \AA$ resolution and led to highquality structures. In these cases, the best data set was chosen to represent each complex. In one case (PDB ID: $5 \mathrm{j} 23)$, NADPH was presumably hydrolyzed in the crystallization mixture due to the acidic environment created by the glycolic acid (Table 3), and the nicotinamide moiety was eliminated from NADPH, producing $2^{\prime}$ - phospho-ADPR, ${ }^{27}$ which was discovered during the structure refinement. Oxalate and 2-keto-D-gluconic acid were explicitly added to the protein samples, but other ligands in the active site (sulfate, malonate, and citrate) were components of the commercial crystallization cocktails used for screening. All experimental details were tracked by the LabDB database. ${ }^{28,29}$ 


\section{Data Processing and Structure Determination.}

Data reduction and scaling for all structures were performed with HKL-3000. ${ }^{30,31}$ The structures were determined by molecular replacement in HKL-3000 integrated with MOLREP $^{32}$ and auxiliary programs from the CCP4 package. ${ }^{33}$ The first structure of SmGhrA (complexed with $\mathrm{NADP}^{+}$and sulfate, PDB ID: 4weq) was solved using the $4 \mathrm{n} 18$ PDB deposit as the template; the first structure of SmGhrB (complexed with NADPH and oxalate, PDB ID: 5v7g) was solved using the 3 baz PDB deposit as the template.

\section{Model Building and Refinement.}

The initial model building was performed with Buccaneer ${ }^{34}$ followed by optimization of side-chain conformations with Fitmunk ${ }^{35}$ as implemented in HKL-3000. After the initial model building and refinement, the atomic models for the first structures were used as templates for solving all other structures by molecular replacement. The structures were refined in HKL-3000 using REFMAC5 ${ }^{36}$ in the restrained mode with isotropic ADPs and hydrogen atoms in riding positions. TLS groups were introduced for all structures in the later stages of refinement as determined by the TLS Motion Determination Server. ${ }^{37}$ Water molecules were not included in the TLS groups. Automatic local NCS was applied throughout refinement for all structures containing more than one subunit in the asymmetric unit. Coot software ${ }^{38}$ was used for the visualization of electron density maps, manual inspection, and correction of the atomic models. Multiple tools integrated into Coot, a standalone version of MolProbity, ${ }^{39}$ and the PDB validation tools ${ }^{40}$ were used for structure quality assessment. The structures of SmGhrA have no Ramachandran plot outliers; some structures of SmGhrB have one outlier in each chain (Asp94) located next to the binding site for the pyrophosphate moiety of the cofactor. These residues are well-defined on the electron density maps. PDB IDs and statistics for data collection, refinement, and validation are summarized in Tables 2 and 3. The diffraction images are available on the Integrated Resource for Reproducibility in Macromolecular Crystallography Web site (http:// proteindiffraction.org/). ${ }^{41}$ The ligands in the active site and the electron density maps, including omit maps, can be inspected interactively using Molstack ${ }^{42}$ at http:// molstack.bioreproducibility.org/c/FdBO/.

\section{RESULTS}

\section{Maximum-Likelihood Phylogenetic Analysis.}

To cluster $2 \mathrm{HADHs}$ into functionally related groups, we performed in-depth phylogenetic analyses. According to the previously reported neighbor-joining phylogenetic tree, ${ }^{10}$ the $2 \mathrm{HADH}$ family can be divided into seven functionally related subfamilies, one of which is the GHPR subfamily. Contrary to this division, our maximum-likelihood tree suggests that sequences previously assigned to the subfamily, in fact, belong to two evolutionary separated clades (Figure 2). The underlying tree topology appears consistently in trees obtained with modified approaches (see Materials and Methods for details).

The larger clade, which we call GHRB, has 16 biochemically characterized members. GHRB shows a broad taxonomic distribution and is consequently highly divergent, including enzymes with diverse substrate and cofactor specificities, such as yeast D- 
mandelate dehydrogenase (UniProt ID: Q7LLW9_RHOGR), 2-ketogluconate reductase (UniProt ID: 2KGR_GLUOX), and bacterial (UniProt ID: GHRB_ECOLI), human (UniProt ID: GRHPR_HUMAN), and plant (UniProt ID: HPR1_ARATH, HPR2_ARATH, HPR3_ARATH) glyoxylate/hydroxypyruvate reductases. ${ }^{14,19,44-46}$ There are 32 GHRB structures reported in the PDB, including six presented herein. Twelve structures have a ligand in the active site (Table 4). Several papers describing some of the GHRB structures have previously been published. ${ }^{18,19,43,47}$

The second clade, which we call GHRA, is bacteria-specific and comprises only two members that have been studied biochemically: ${ }^{10,16}$ E. coli EcGhrA (UniProt ID: GHRA_ECOLI) and R. etli ReGxrA (UniProt ID: C1JH53_RHIET). Thirteen structures of the GHRA subfamily have been determined so far, including three reported herein. Six structures have a ligand bound in the active site (Table 4), but no papers describing the GHRA structures have been published.

In all reconstructed trees, one of the sister clades of GHRA includes a 2HADH from Haloferax mediterranei (UniProt ID: DDH_HALMT), which reduces 2-ketocarboxylic acids with an unbranched chain of 4-5 carbon atoms. ${ }^{48}$ The consistent placement of the two clades (GHRA and ddh) in relation to GHRB supports the validity of the tree and the polyphyletic origin of GHRA and GHRB enzymes.

\section{Protein Purification and Substrate Screening.}

To dissect differences between the GHRA and GHRB subfamilies, we selected SmGhrA (locus tag SMc02828) and SmGhrB (SMc04462) as their representatives, respectively, for further experimental studies. We heterologously expressed and purified SmGhrA and SmGhrB as described in Materials and Methods. Using NADP $(\mathrm{H})$ as a cofactor, we performed an activity screening with 24 selected compounds at concentrations expected to be saturating for physiological substrates (Tables S3 and S4). The compounds were chosen to include those reported in literature for other GHRA and GHRB members and based on known biochemical pathways that involve 2-ketocarboxylic acids. The selected compounds included seventeen 2-ketocarboxylic acids and seven 2-hydroxycarboxylic acids; consequently, both reductase and dehydrogenase activities were tested. The enzyme activity was observed for at least one enzyme with thirteen 2-ketocarboxylic acids. No detectable activity with reduced substrates was observed (Table S4), suggesting that these enzymes act only as reductases.

\section{Steady-State Kinetics for Selected Substrates.}

To explore detailed kinetic characteristics of both enzymes, we performed steady-state kinetic assays with selected compounds that resulted in the most prominent activity in the preliminary screening and with pyruvate, which showed poor activity in the screening yet is a substrate for some GHRB enzymes (Table S3). After determining the initial rates of the reaction, we attempted to fit the data to both hyperbolic and sigmoidal curves, by calculating parameters of the Michaelis-Menten and Hill equations with the nonlinear least-squares method. Using an ANOVA F-test at $\mathrm{p}=0.01$, we assessed which model better fit the data. The kinetic parameters $\left(\mathrm{K}_{\mathrm{m}}\right.$ or $\mathrm{K}_{0.5}$, generally expressed as $\mathrm{K}_{0.5}$, turnover number $\mathrm{k}_{\mathrm{cat}}$, and 
$\mathrm{k}_{\mathrm{cat}} / \mathrm{K}_{0.5}$ ) were calculated only for substrates with relatively high affinity to the enzyme (i.e., with $\mathrm{K}_{0.5}$ values falling within the tested concentration ranges; Table 1, Figure S1).

For each enzyme, we were able to obtain catalytic parameters for four substrates: glyoxylate, hydroxypyruvate, phenylpyruvate, and pyruvate for SmGhrA and glyoxylate, hydroxypyruvate, phenylpyruvate, and 2-keto-D-gluconate for SmGhrB (Table 1, Figure S1). Due to the high absorption of 4-hydroxyphenylpyruvate at $340 \mathrm{~nm}$, we were not able to reliably measure initial velocities of the reduction reaction. Preliminary measurements of fluorescence at $340 \mathrm{~nm}$ suggested that 4-hydroxyphenylpyruvate may be an efficient substrate for both SmGhrA and SmGhrB (data not shown).

Interestingly, all but three steady-state reactions exhibit standard Michaelis-Menten behavior. The Hill equation better fits the observed data $(\mathrm{p}<0.01)$ for both SmGhrA and SmGhrB with glyoxylate ( $\mathrm{n}=1.83$ and 1.48 , respectively) and for SmGhrB with hydroxypyruvate $(n=1.74)$. This observation suggests that the efficient substrates of both enzymes also positively regulate their activities.

Glyoxylate and hydroxypyruvate, which are known substrates for other GHRA representatives (e.g., EcGhrA and ReGxrA) and most GHRB members, are two of the most efficient substrates for both SmGhrA and SmGhrB. SmGhrA exhibits its highest catalytic efficiency $\left(\mathrm{k}_{\text {cat }} / \mathrm{K}_{0}\right.$ ) with glyoxylate due to its high $\mathrm{k}_{\text {cat }}$, albeit with slightly lower affinity (as indicated by the respective $\mathrm{K}_{\mathrm{m}}$ or $\mathrm{K}_{0.5}$ values). $\mathrm{SmGhrB}$ shows lower catalytic effectiveness with glyoxylate due to a poor $\mathrm{K}_{0.5}$ for this substrate. Conversely, SmGhrB exhibits its highest catalytic effectiveness with hydroxypyruvate, with an unusually high $\mathrm{k}_{\text {cat }}$ and ordinary $\mathrm{K}_{0.5}$. The enzymes show similar catalytic parameters with respect to phenylpyruvate. The main difference observed between the enzymes is that only SmGhrA reduces pyruvate, with $K_{m}=9.7 \mathrm{mM}$, whereas only SmGhrB reduces 2-keto-D-gluconate, with $\mathrm{K}_{\mathrm{m}}=11 \mathrm{mM}$. The broad substrate specificities, similar catalytic efficiencies, and rather low affinities for even the most prominent substrates suggest that both studied proteins are enzymatic generalists with, to some extent, redundant functionalities. However, it cannot be excluded that despite the extensive selection of 24 compounds used for substrate screening, the optimal substrate is yet to be found.

\section{Cofactor Specificity.}

With hydroxypyruvate as a substrate at a saturating concentration $(66.7 \mathrm{mM})$, both enzymes exhibited 2-3\% activity with $0.4 \mathrm{mM}$ NADH as compared to $0.4 \mathrm{mM}$ NADPH (data not shown). This observation is supported by the results of thermal shift assays: $\mathrm{NAD}^{+}$and NADH did not stabilize the enzymes, whereas $\mathrm{NADP}^{+}$and NADPH resulted in increases of melting temperatures by $2.0-5.5^{\circ} \mathrm{C}$ (Table S2). Steady-state kinetic assays showed that SmGhrA has a 6-fold smaller $\mathrm{K}_{\mathrm{m}}$ for the preferential cofactor NADPH than SmGhrB (Table 1, Figure S2), suggesting stronger cofactor binding by SmGhrA.

\section{Overall Fold and Core Catalytic Residues of SmGhrA and SmGhrB.}

To gain insight into structural differences between the two enzymes, we determined three structures for $S m G h r A$ and six structures for $S m G h r B$ at 1.7-2.4 $\AA$ resolution, both in apo 
forms and in various complexes (Tables 2 and 3). The refined models have good overall geometry with a very low percentage of rotamer outliers and low MolProbity clashscore.

In the solved crystal structures, both enzymes are symmetrical homodimers composed of 319 and 322 amino acids (Figure 3). PISA server analysis ${ }^{49}$ showed the average dimer interface area for the cofactor-bound forms to be $2183 \AA^{2}$ for SmGhrA and $2268 \AA^{2}$ for SmGhrB; this, together with the size-exclusion chromatography results (data not shown), strongly suggests that the proteins also exist as homodimers in solution. The monomers comprise two globular a/ $\beta / \alpha$ domains: a coenzyme-binding domain (residues 96-286 in SmGhrA; 95-281 in SmGhrB) and a catalytic domain (1-95 and 287-319 in SmGhrA; 1-94 and 282-322 in SmGhrB). The coenzymebinding domain of the classical NAD(P)H-binding Rossmann fold acts as a dimerization domain. The substrate and cofactor bind in the cleft between those two domains, causing the cleft closure (Figure 3). The cofactor is bound mostly to the coenzyme domain in a manner canonical for Rossmann-fold enzymes (Figure 3 and 4), as described previously. ${ }^{50}$

The core catalytic residues typical for 2HADHs-Arg234/230 (binding and charge compensation; residues refer to SmGhrA/SmGhrB, respectively), His282/277 (binding and proton transfer), Glu263/259 (maintenance of the protonated state of His282/277), and Ala74/Val72-Gly75/73 (binding of the carboxyl group via main chain) ${ }^{51}$-are spatially conserved in the SmGhrA and SmGhrB structures (Figure 5).

\section{Structures of SmGhrA.}

Cofactor-bound forms of SmGhrA (complexes with NADP ${ }^{+}$and sulfate and with NADPH and oxalate) have only one protein chain in the asymmetric unit; the dimer in these structures is formed via the crystallographic twofold axis (Table 2). With the exception of three $\mathrm{N}$-terminal residues, all residues, including the C-terminal residue Tyr319, were modeled into the electron density maps. The cofactor-bound structures of SmGhrA are highly similar to each other, with $\mathrm{Ca}$ atom root-mean-square deviation (rmsd) of $0.21 \AA$ and maximum $\mathrm{Ca}$ deviation of $0.69 \AA$ In addition to binding by the coenzyme-binding domain, the cofactor has two strong interactions with the catalytic domain. The $\mathrm{OH}$ group of the $\mathrm{C}$ terminal residue Tyr319 forms a hydrogen bond with the $2^{\prime}$ - phosphate group, and the positively charged side chain of $\operatorname{Arg} 92$ forms at least two hydrogen bonds with the pyrophosphate moiety and serves as the charge compensator (Figure 4).

Superposition of the two cofactor-bound structures shows that despite the high similarity of the two cofactor-bound complexes, there are small adjustments in the active site depending on the ligand. In the complex with sulfate, the side chain of Trp53 moves down by $0.50 \AA$, and that of $\operatorname{Arg} 234$ moves away by $0.40 \AA$ in order to accommodate the sulfate, which is a more bulky ligand as compared to nearly flat oxalate (Figure 5A,B).

The structure with oxalate displays a three-point fixation of this substrate analogue, where all three oxygen atoms that are equivalent to the core of the substrate (carboxyl and keto groups) are bound by the protein (Figure 5A). This mode of binding is similar to that in the SmGhrB complex with NADP ${ }^{+}$and 2-keto-D-gluconate (Figure 5E) and in the HsGhrB complex with $\mathrm{NADP}^{+}$and hydroxypyruvate (Figure $5 \mathrm{~F}$ ). These structures suggest that the 
position of the actual substrate in SmGhrA should be similar to that in SmGhrB and HsGhrB. The carboxyl group of the substrate will be bound by the hydrogen bonds with the main-chain nitrogen atoms of Gly 73 and Gly 75 from the catalytic domain, as well as with the guanidine group of Arg234 from the coenzyme-binding domain. The variable radical of the 2-ketocarboxylic acid will be located at the position of the unbound oxygen atom. The keto group of the substrate will be bound by the hydrogen bonds with Arg234 and His282 from the coenzyme-binding domain. Thus, the substrate serves as a linker between the domains.

The apo form of SmGhrA has two protein chains in the asymmetric unit. The catalytic domain is highly disordered: it was possible to build only $\sim 30 \%$ of the catalytic domain residues in chain A and just a few residues in chain B (Figure 3A). The catalytic domain occupies several different conformations in each subunit (which can be easily accommodated by the crystal lattice), and only a major conformation is visible in chain A. Although the apo form could not be fully reconstructed, a comparison to the cofactor-bound form shows a major rotation of the catalytic domain upon NADPH binding $\left(\sim 30^{\circ}\right.$, Figures $3 \mathrm{~A}, \mathrm{C}$ and $\mathrm{S} 3 \mathrm{~A})$. At the same time, there are no significant changes observed in the coenzyme-binding domain upon $\mathrm{NADP}(\mathrm{H})$ binding, suggesting that the domain is preorganized for cofactor binding.

Interestingly, in the structures of SmGhrA complexes with (1) $\mathrm{NADP}^{+}$and sulfate and (2) NADPH and oxalate, the same small ligands were found in the interdomain interface as in the active site (sulfate and oxalate, Figure 3C). The binding of these ligands might cause the potential allosteric regulation, suggested by the sigmoidal kinetic behavior in the reduction of glyoxylate by SmGhrA.

\section{Structures of SmGhrB.}

All six structures of SmGhrB have four protein chains in the asymmetric unit, forming two dimers (Table 2). Unlike SmGhrA, almost all residues, except for the first two N-terminal and the last three $\mathrm{C}$-terminal residues, showed electron density and were modeled in all SmGhrB structures, including the apo forms.

The structures of SmGhrB complexed with (1) $\mathrm{NADP}^{+}$and 2-keto-D-gluconate, (2) NADPH and oxalate, (3) $\mathrm{NADP}^{+}$and malonate, and (4) $2^{\prime}$-phospho-ADPR are very structurally similar to each other. The complex containing $2^{\prime}$-phospho-ADPR has the same closed conformation as all three ternary complexes, suggesting that the major domain movement can occur upon cofactor binding even without a substrate present. The pairwise $\mathrm{Ca}$ atom superposition of all enzyme subunits from these structures shows rmsd values in the range of 0.19-0.41 $\AA$, with a maximum Ca deviation of $1.20 \AA$ A , suggesting substantial rigidity of these complexes. In contrast to SmGhrA, the cofactor is bound solely by the coenzymebinding domain (Figure 4C,D).

SmGhrB's active site displays the same three-point fixation of the core of the substrate (carboxyl and keto groups) as SmGhrA and HsGhrB, with the same types of residues involved for both the substrate and substrate analogues (Figure 5). The substrate analogues (oxalate and malonate) are bound only via the three points in the same way as in the 
SmGhrA structures. Remarkably, 2-keto-D-gluconate-the biggest substrate bound in the active site in all reported 2HADH structures-forms two additional hydrogen bonds. First, the hydroxyl group on the $\mathrm{C} 3$ carbon of 2-keto-D-gluconate is bound by the side chain of Ser280 in the same manner that hydroxypyruvate is bound in the HsGhrB structure (Figure 5F). Second, the hydroxyl group on $\mathrm{C} 5$ of this substrate is bound by the side chain of the catalytic residue $\operatorname{Arg} 230$.

Two structures of the apo form of SmGhrB were solved: the unliganded form and the complex with citrate (Table 3). The latter complex has citrate bound in the active site in one of the four subunits. The citrate molecule is located in the place of the nicotinamide moiety of the cofactor, suggesting that it might be a competitive inhibitor of NADPH binding. Comparison of cofactor-free and cofactor-bound structures show that SmGhrB's catalytic domain has some degree of flexibility with respect to its positioning (Figure S3B); this rotation, however, is much smaller than that observed in SmGhrA (Figures 3 and S3). Furthermore, SmGhrB displays much higher flexibility of the cofactor-binding pocket in the cofactor-free forms: the loop comprising residues 201-209 occupies different conformations in different complexes and even different subunits, and the loop comprising residues 228233 has a different conformation in subunit A of the citrate complex structure (Figure S3B). The catalytic domain is highly similar in all SmGhrB structures, suggesting that it moves as a rigid body upon cofactor binding.

\section{DISCUSSION}

In this work, we show a clear separation of enzymes previously known as GHPR into two evolutionary separated subfamilies. In contrast to the previous studies, our maximumlikelihood phylogenetic analysis shows that most GHPRs form two separate clades, GHRA and GHRB. Our substrate screening and steady-state kinetic studies of two representative proteins from GHRA and GHRB of S. meliloti show broad substrate versatility of these enzymes with similar substrate preferences, albeit with clear differences in specificities for some substrates (e.g., 2-keto-D-gluconate and pyruvate). SmGhrA and SmGhrB exhibit greatest catalytic efficiency (as shown with $\mathrm{k}_{\mathrm{cat}} / \mathrm{K}_{0.5}$ ) with glyoxylate and hydroxypyruvate, respectively, and none of the enzymes catalyzes the reverse reaction. These results suggest that SmGhrA and SmGhrB are glyoxylate/hydroxypyruvate reductases with broad and somewhat overlapping substrate specificities.

We present nine crystal structures of two hereto unstudied enzymes with a series of substrates/substrate analogues and cofactors along with the enzymes' apo forms. In particular, we determined the crystal structure of SmGhrB with 2-keto-D-gluconate, which is the biggest substrate (by the number of atoms) cocrystallized with any $2 \mathrm{HADH}$. Moreover, the complex with 2-keto-D-gluconate is just the second reported ternary complex of GHRA/ GHRB with an actual substrate (not a substrate analogue, Table 4). This structure represents a complex with the substrate for the direct reaction (reduction), and a previously reported structure (PDB ID: $2 \mathrm{gcg}$ ) represents a complex with a substrate for the reverse reaction (oxidation). Apart from these two structures, the PDB contains 16 structures of GHRA/ GHRB enzymes with a ligand bound in the active site (including those reported herein). Most of these structures, however, have active-site ligands that are either substrate analogues 
(which may bind differently, as shown by PDB ID: 5bqf) or wrongly modeled substrates (PDB ID: 5aow and 5aov, Table 4). To resolve one case of an incorrectly modeled substrate in the active site, we took the liberty of using the deposited structure factors to rerefine and redeposit the structure 5aow. Our rerefinement (PDB ID: 6bii) shows that the actual ligand is malonate ion, which was present at $1.7 \mathrm{M}$ concentration in the crystallization solution (http://molstack.bioreproducibility.org/c/FdBO/). The structure of SmGhrB complexed with 2-keto-D-gluconate provides further experimental support for the mode of substrate binding observed previously for the complex of HsGhrB with substrate hydroxypyruvate (Figure $5 \mathrm{~F}) .^{18}$

Superposition of the SmGhrA and SmGhrB structures shows substantial structural differences between the overall folds of these enzymes (Figure S4). Most of the differences are within the catalytic domains; coenzyme-binding domains are much more conserved structurally, as supported by the sequence alignment (Figure S5).

In line with differences in catalytic behavior of the two enzymes, substantial differences are also observed within the substrate-binding pocket (Figure 5). The SmGhrA structures reveal a smaller binding site due to the bulky and hydrophobic Trp53 residue. Consequently, 2keto-D-gluconate- a large compound-is reduced only by SmGhrB and not by SmGhrA. In GHRA, Trp53 is highly conserved, suggesting that a smaller substrate-binding site is a feature of this subfamily. In GHRB, Trp53 corresponds to Ser50 in SmGhrB and Leu59 in $\mathrm{HsGhrB}$, which are located in a highly variable sequence region (Figure S5). This variability suggests higher diversity in substrate specificities in the GHRB subfamily.

Despite high sequence variability, GHRB enzymes possess an active site feature that is characteristic of most members of the subfamily: residue Ser280/Ser296 (SmGhrB/HsGhrB numbering), which binds hydroxypyruvate via its hydroxyl group (Figure 5). This residue is likely responsible for making hydroxypyruvate the most prominent substrate for SmGhrB, which is a typical case for GHRB. ${ }^{16}$ Moreover, it likely accounts for the inactivity of SmGhrB with pyruvate, due to potential clashes between serine's side chain and pyruvate's methyl group. In SmGhrA, Ser280 corresponds to the well-conserved Ala285, suggesting that weak activity with pyruvate can be preserved within the GHRA subfamily. SmGhrA substrate-binding site also has a unique feature: the bulky Met102 and Leu150 residues (Val100 and Ile153 in SmGhrB) on the side opposite the nicotinamide moiety of the cofactor. These residues are highly conserved in GHRA (Figure S5) and are likely involved in increasing the catalytic efficiency of these enzymes by pushing the cofactor toward the substrate.

SmGhrA and SmGhrB display strong preferences for NADP $(H)$ over NAD $(H)$, as shown by the thermal shift and kinetic data. As revealed by the crystal structures, the preference is enabled by the S(T)RS(T)XR(K) motif (Figure 4B,D). Ser169 in SmGhrA and Thr172 in SmGhrB are neutrally charged and not bulky, allowing for the accommodation of the $2^{\prime}$ phosphate group. Two positively charged arginine residues near the negatively charged $2^{\prime}$ phosphate moiety (Arg170 and Arg 173 in SmGhrA; Arg173 and Arg176 in SmGhrB) assist NADP $(H)$ binding via charge neutralization and hydrogen bonds. In addition, Ser171 in SmGhrA and Thr174 in SmGhrB form hydrogen bonds with the phosphate group. 
The multiple sequence alignment suggests that this preference for NADPH is highly ubiquitous for the GHRA subfamily due to the conservation of the $\mathrm{S}(\mathrm{T}) \mathrm{RS}(\mathrm{T}) \mathrm{XR}(\mathrm{K})$ motif (Figures 4B,D and S5). This cofactor preference agrees with the previously reported data for EcGhrA ${ }^{16}$ but not for ReGxrA, which was shown to reduce substrates only with NADH. ${ }^{10}$ The sequence of ReGxrA (UniProt ID: C1JH53_RHIET), however, has the characteristic SRTRK motif (Figure 4A). Additionally, crystal structures of a similar GHRA enzyme from R. etli with $84 \%$ identity to ReGxrA have bound NADP(H) (PDB IDs: 5bqf, 4xcv, and 5tds), which is inconsistent with the original publication. ${ }^{10}$ The same motif is also common for the GHRB subfamily; however, several GHRB enzymes have Thr172 of SmGhrB substituted by Asp-a typical mutation responsible for specificity for $\mathrm{NAD}(\mathrm{H})$ versus NADP $(\mathrm{H}) .{ }^{52}$ This phenomenon is always accompanied by mutations of both aforementioned arginine residues, further pinpointing the specificity toward NADH for these GHRB members. Thus, our kinetic, structural, and sequence data suggest that GHRA enzymes are highly specific for NADPH, whereas the GHRB subfamily includes members that are specific for either NADH or NADPH.

The apo form protein structures suggest that the interdomain cleft opening is at least twice wider in SmGhrA than in SmGhrB (Figure 3), which is a general trend for GHRA and GHRB enzymes. Higher SmGhrA flexibility is associated with the catalytic domain involvement in the cofactor binding via residues Arg92 and Tyr319 (Figure 4A), which may assist with the closure of the wide-open interdomain cleft prior to catalysis. The residues are highly conserved within the GHRA subfamily, suggesting that this mode of the cofactor binding is common for the GHRA enzymes (Figure S5). In addition, the results of steadystate kinetics suggest stronger cofactor binding by SmGhrA as compared to SmGhrB (Table 1), which may also be caused by the involvement of the catalytic domain in the cofactor binding. The stronger cofactor binding may be a feature of the GHRA subfamily, but this hypothesis is yet to be proven by comparison of binding data. On the contrary, the catalytic domain is not involved in the cofactor binding in SmGhrB, and the coenzyme-binding domain residue Arg152, which binds the pyrophosphate moiety of the cofactor in SmGhrB instead of Arg92 in SmGhrA (Figure 4C), is highly conserved within the GHRB subfamily.

The broad and overlapping substrate specificities of the GHRA and GHRB subfamilies suggest that their functional specializations might have arisen from acquired differences in gene expression and subsequent adaptation to specific roles in metabolic pathways. The genome of S. meliloti 1021 encodes sixteen 2HADH members, including two GHRA and seven GHRB members, some of which result from very recent duplications (Figure 2). SmGhrA is a highly similar orthologue of the previously characterized ReGxrA protein (61\% sequence identity). Their corresponding genes are potentially coexpressed with genes encoding the Yej transporter, a member of the ABC superfamily of transporters (Figure S6). Interestingly, there is one GHRA member encoded in the genome of the sea anemone Nematostella vectensis (UniProt ID: A8DWN5_NEMVE). It can function in the glyoxylate cycle or shikimic acid pathway, which previously were suggested as horizontally transferred from bacteria. ${ }^{53}$ The gene encoding SmGhrB, similarly to its close orthologues from Rhizobiales, is located downstream to pckR, and together they presumably form an operon (Figure S6) ${ }^{54}$ PckR is a LacI-like transcription factor predicted to be involved in the regulation of central carbohydrate metabolism. ${ }^{55}$ Thus, the genomic data suggest that 
SmGhrA and SmGhrB are expressed under different conditions, adopting different metabolic or signaling roles in the cell.

Cumulatively, the division of GHPR into GHRA and GHRB subfamilies is strongly supported by the conserved structural features of these enzymes that can be linked to the observed differences in substrate preferences. Thus, our work advances the systematic classification of the $2 \mathrm{HADH}$ family, presents broad kinetic and structural characterizations of the two selected members, and constitutes the first systematic effort to investigate differences between the GHRA and GHRB subfamilies. Further studies are required to understand why GHRA and GHRB have remained generalists over the course of evolution and how their functions differ in vivo.

\section{Supplementary Material}

Refer to Web version on PubMed Central for supplementary material.

\section{ACKNOWLEDGMENTS}

We thank David Cooper, Matthew Zimmerman, and Barat Venkataramany for critically reading the manuscript.

Funding

This work was supported by NIGMS grants U54-GM094662 and R01-GM117080 and NIH Big Data to Knowledge (BD2K) grant HG008424. The project was also supported by NCN (Maestro, No. UMO-2012/04/A/ST5/00609; Opus, No. UMO-2014/15/B/NZ1/03357) and FNP (TEAM) grants. Results shown in this article are derived from work performed at Argonne National Laboratory, Structural Biology Center at the Advanced Photon Source. Argonne is operated by UChicago Argonne, LLC, for the U.S. Department of Energy, Office of Biological and Environmental Research under contract DE-AC02-06CH11357. Use of the LS-CAT Sector 21 was supported by the Michigan Economic Development Corporation and the Michigan Technology Tri-Corridor (grant 085P1000817).

\section{ABBREVIATIONS}

2HADH

GHPR

GHRA and GHRB

SmGhrA and $S m$ GhrB

HsGhrB (HsGRHPR)

EcGhrA and EcGhrB

$\operatorname{ReGxrA}$

IPTG

PDB

rTEV
D-2-hydroxyacid dehydrogenase

previously delineated glyoxylate/hydroxypyruvate reductase subfamily of $2 \mathrm{HADH}$

glyoxylate/hydroxypyruvate reductase subfamilies A and B (defined in this work)

GHRA (SMc02828) and GHRB (SMc04462) from

Sinorhizobium meliloti

human GHRB

GHRA and GHRB from Escherichia coli

GHRA from Rhizobium etli

isopropyl $\beta$-D-thiogalactopyranoside

Protein Data Bank

recombinant Tobacco Etch Virus protease 


\section{REFERENCES}

(1). Stoll VS, Manohar AV, Gillon W, MacFarlane EL, Hynes RC, and Pai EF (1998) A thioredoxin fusion protein of VanH, a D-lactate dehydrogenase from Enterococcus faecium: cloning, expression, purification, kinetic analysis, and crystallization. Protein Sci. 7, 1147-1155. [PubMed: 9605319]

(2). Zou Y, Zhang H, Brunzelle JS, Johannes TW, Woodyer R, Hung JE, Nair N, van der Donk WA, Zhao H, and Nair SK (2012) Crystal structures of phosphite dehydrogenase provide insights into nicotinamide cofactor regeneration. Biochemistry 51, 4263-4270. [PubMed: 22564171]

(3). Tarmy EM, and Kaplan NO (1968) Kinetics of Escherichia coli B D-lactate dehydrogenase and evidence for pyruvate-controlled change in conformation. J. Biol. Chem 243, 2587-2596. [PubMed: 4297266]

(4). Kleczkowski LA, and Randall DD (1988) Purification and characterization of a novel $\mathrm{NADPH}(\mathrm{NADH})$-dependent hydroxypyruvate reductase from spinach leaves. Comparison of immunological properties of leaf hydroxypyruvate reductases. Biochem. J 250, 145-152. [PubMed: 3281657]

(5). Cramer SD, Ferree PM, Lin K, Milliner DS, and Holmes RP (1999) The gene encoding hydroxypyruvate reductase (GRHPR) is mutated in patients with primary hyperoxaluria type II. Hum. Mol. Genet 8, 2063-2069. [PubMed: 10484776]

(6). Xue YP, Zeng H, Jin XL, Liu ZQ, and Zheng YG (2016) Enantioselective cascade biocatalysis for deracemization of 2-hydroxy acids using a three-enzyme system. Microb. Cell Fact 15, 162. [PubMed: 27659410]

(7). Patel RN (2013) Biocatalytic synthesis of chiral alcohols and amino acids for development of pharmaceuticals. Biomolecules 3, 741-777. [PubMed: 24970190]

(8). Hummel W (1999) Large-scale applications of NAD(P)-dependent oxidoreductases: recent developments. Trends Biotechnol. 17, 487-492. [PubMed: 10557162]

(9). Grant GA (1989) A new family of 2-hydroxyacid dehydrogenases. Biochem. Biophys. Res. Commun 165, 1371-1374. [PubMed: 2692566]

(10). Fauvart M, Braeken K, Daniels R, Vos K, Ndayizeye M, Noben JP, Robben J, Vanderleyden J, and Michiels J (2007) Identification of a novel glyoxylate reductase supports phylogeny-based enzymatic substrate specificity prediction. Biochim. Biophys. Acta, Proteins Proteomics 1774, 1092-1098.

(11). Fujii T, Shimizu M, Doi Y, Fujita T, Ito T, Miura D, Wariishi H, and Takaya N (2011) Novel fungal phenylpyruvate reductase belongs to d-isomer-specific 2-hydroxyacid dehydrogenase family. Mochim. Biophys. Acta, Proteins Proteomics 1814, 1669-1676.

(12). Baker DP, Kleanthous C, Keen JN, Weinhold E, and Fewson CA (1992) Mechanistic and activesite studies on $\mathrm{D}(-)$-mandelate dehydrogenase from Rhodotorula graminis. Biochem. J 281, 211218. [PubMed: 1731758]

(13). Lassalle L, Engilberge S, Madern D, Vauclare P, Franzetti B, and Girard E (2016) New insights into the mechanism of substrates trafficking in Glyoxylate/Hydroxypyruvate reductases. Sci. Rep 6, 20629. [PubMed: 26865263]

(14). Costas AM, White AK, and Metcalf WW (2001) Purification and characterization of a novel phosphorus-oxidizing enzyme from Pseudomonas stutzeri WM88. J. Biol. Chem 276, 1742917436. [PubMed: 11278981]

(15). Kim KH, Janiak V, and Petersen M (2004) Purification, cloning and functional expression of hydroxyphenylpyruvate reductase involved in rosmarinic acid biosynthesis in cell cultures of Coleus blumei. Plant Mol. Biol 54, 311-323. [PubMed: 15284489]

(16). Nunez MF, Pellicer MT, Badia J, Aguilar J, and Baldoma L (2001) Biochemical characterization of the 2-ketoacid reductases encoded by ycdW and yiaE genes in Escherichia coli. Biochem. $\mathrm{J}$ 354, 707-715. [PubMed: 11237876]

(17). Duan X, Hu S, Zhou P, Zhou Y, Liu Y, and Jiang Z (2014) Characterization and crystal structure of a first fungal glyoxylate reductase from Paecilomyes thermophila. Enzyme Microb. Technol 60, 72-79. [PubMed: 24835102] 
(18). Booth MP, Conners R, Rumsby G, and Brady RL (2006) Structural basis of substrate specificity in human glyoxylate reductase/hydroxypyruvate reductase. J. Mol. Biol 360, 178-189. [PubMed: 16756993]

(19). Yoshikawa S, Arai R, Kinoshita Y, Uchikubo-Kamo T, Wakamatsu T, Akasaka R, Masui R, Terada T, Kuramitsu S, Shirouzu M, and Yokoyama S (2007) Structure of archaeal glyoxylate reductase from Pyrococcus horikoshii OT3 complexed with nicotinamide adenine dinucleotide phosphate. Acta Crystallogr., Sect. D: Biol. Crystallogr 63, 357-365. [PubMed: 17327673]

(20). Jones KM, Kobayashi H, Davies BW, Taga ME, and Walker GC (2007) How rhizobial symbionts invade plants: the Sinorhizobium-Medicago model. Nat. Rev. Microbiol 5, 619-633. [PubMed: 17632573]

(21). Galibert F, Finan TM, Long SR, Puhler A, Abola P, Ampe F, Barloy-Hubler F, Barnett MJ, Becker A, Boistard P, Bothe G, Boutry M, Bowser L, Buhrmester J, Cadieu E, Capela D, Chain P, Cowie A, Davis RW, Dreano S, Federspiel NA, Fisher RF, Gloux S, Godrie T, Goffeau A, Golding B, Gouzy J, Gurjal M, Hernandez-Lucas I, Hong A, Huizar L, Hyman RW, Jones T, Kahn D, Kahn ML, Kalman S, Keating DH, Kiss E, Komp C, Lelaure V, Masuy D, Palm C, Peck MC, Pohl TM, Portetelle D, Purnelle B, Ramsperger U, Surzycki R, Thebault P, Vandenbol M, Vorholter FJ, Weidner S, Wells DH, Wong K, Yeh KC, and Batut J (2001) The composite genome of the legume symbiont Sinorhizobium meliloti. Science 293, 668-672. [PubMed: 11474104]

(22). UniProt Consortium (2015) UniProt: a hub for protein information. Nucleic Acids Res. 43, D204-D212. [PubMed: 25348405]

(23). Katoh K, and Standley DM (2013) MAFFT multiple sequence alignment software version 7: improvements in performance and usability. Mol. Biol. Evol 30, 772-780. [PubMed: 23329690]

(24). Capella-Gutierrez S, Silla-Martinez JM, and Gabaldon T (2009) trimAl: a tool for automated alignment trimming in large-scale phylogenetic analyses. Bioinformatics 25, 1972-1973. [PubMed: 19505945]

(25). Price MN, Dehal PS, and Arkin AP (2010) FastTree 2-approximately maximum-likelihood trees for large alignments. PLoS One 5, e9490. [PubMed: 20224823]

(26). Han MV, and Zmasek CM (2009) phyloXML: XML for evolutionary biology and comparative genomics. BMC Bioinf. 10, 356.

(27). Tong L, Lee S, and Denu JM (2009) Hydrolase regulates NAD+ metabolites and modulates cellular redox. J. Biol. Chem 284, 11256-11266. [PubMed: 19251690]

(28). Zimmerman MD, Grabowski M, Domagalski MJ, Maclean EM, Chruszcz M, and Minor W (2014) Data management in the modern structural biology and biomedical research environment. Methods Mol. Biol 1140, 1-25. [PubMed: 24590705]

(29). Berman HM, Gabanyi MJ, Groom CR, Johnson JE, Murshudov GN, Nicholls RA, Reddy V, Schwede T, Zimmerman MD, Westbrook J, and Minor W (2015) Data to knowledge: how to get meaning from your result. IUCrJ 2, 45-58.

(30). Minor W, Cymborowski M, Otwinowski Z, and Chruszcz M (2006) HKL-3000: the integration of data reduction and structure solution-from diffraction images to an initial model in minutes. Acta Crystallogr., Sect. D: Biol. Crystallogr 62, 859-866. [PubMed: 16855301]

(31). Otwinowski Z, and Minor W (1997) [20] Processing of X-ray diffraction data collected in oscillation mode. Methods Enzvmol 276, 307-326.

(32). Vagin A, and Teplyakov A (2010) Molecular replacement with MOLREP. Acta Crystallogr., Sect. D: Biol. Crystallogr 66, 22-25. [PubMed: 20057045]

(33). Winn MD, Ballard CC, Cowtan KD, Dodson EJ, Emsley P, Evans PR, Keegan RM, Krissinel EB, Leslie AG, McCoy A, McNicholas SJ, Murshudov GN, Pannu NS, Potterton EA, Powell HR, Read RJ, Vagin A, and Wilson KS (2011) Overview of the CCP4 suite and current developments. Acta CrystallogrCrystallogr., Sect. D: Biol. Crystallogr 67, 235-242.

(34). Cowtan K (2006) The Buccaneer software for automated model building. 1. Tracing protein chains. Acta Crystallogr., Sect. D: Biol. Crystallogr 62, 1002-1011. [PubMed: 16929101]

(35). Porebski PJ, Cymborowski M, Pasenkiewicz-Gierula M, and Minor W (2016) Fitmunk: improving protein structures by accurate, automatic modeling of side-chain conformations. Acta Crystallogr. D Biol. Crystallogr 72, 266-280. 
(36). Murshudov GN, Vagin AA, and Dodson EJ (1997) Refinement of macromolecular structures by the maximum-likelihood method. Acta Crystallogr., Sect. D: Biol. Crystallogr 53, 240-255. [PubMed: 15299926]

(37). Painter J, and Merritt EA (2006) Optimal description of a protein structure in terms of multiple groups undergoing TLS motion. Acta Crystallogr., Sect. D: Biol. Crystallogr 62, 439-450. [PubMed: 16552146]

(38). Emsley P, and Cowtan K (2004) Coot: model-building tools for molecular grappas. Acta Crystallogr., Sect. D: BioL Crystallogr 60, 2126-2132. [PubMed: 15572765]

(39). Chen VB, Arendall WB 3rd, Headd JJ, Keedy DA, Immormino RM, Kapral GJ, Murray LW, Richardson JS, and Richardson DC (2010) MolProbity: all-atom structure validation for macromolecular crystallography. Acta Crystallogr., Sect. D: Biol. Crystallogr 66, 12-21. [PubMed: 20057044]

(40). Read RJ, Adams PD, Arendall WB 3rd, Brunger AT, Emsley P, Joosten RP, Kleywegt GJ, Krissinel EB, Lutteke T, Otwinowski Z, Perrakis A, Richardson JS, Sheffler WH, Smith JL, Tickle IJ, Vriend G, and Zwart PH (2011) A new generation of crystallographic validation tools for the protein data bank. Structure 19, 1395-1412. [PubMed: 22000512]

(41). Grabowski M, Langner KM, Cymborowski M, Porebski PJ, Sroka P, Zheng H, Cooper DR, Zimmerman MD, Elsliger MA, Burley SK, and Minor W (2016) A public database of macromolecular diffraction experiments. Acta Crystallogr. D Biol. Crystallogr 72, 1181-1193.

(42). Porebski PJ, Sroka P, Zheng H, Cooper DR, and Minor W (2018) Molstack - interactive visualization tool for presentation, interpretation, and validation of macromolecules and electron density maps. Protein Sci 27, 86-94. [PubMed: 28815771]

(43). Hung JE, Fogle EJ, Garg N, Chekan JR, Nair SK, and van der Donk WA (2014) Chemical rescue and inhibition studies to determine the role of Arg301 in phosphite dehydrogenase. PLoS One 9, e87134. [PubMed: 24498026]

(44). Mdluli K, Booth MP, Brady RL, and Rumsby G (2005) A preliminary account of the properties of recombinant human Glyoxylate reductase (GRHPR), LDHA and LDHB with glyoxylate, and their potential roles in its metabolism. Biochim. Biophys. Acta, Proteins Proteomics 1753, 209H6.

(45). Timm S, Nunes-Nesi A, Parnik T, Morgenthal K, Wienkoop S, Keerberg O, Weckwerth W, Kleczkowski LA, Fernie AR, and Bauwe H (2008) A cytosolic pathway for the conversion of hydroxypyruvate to glycerate during photorespiration in Arabidopsis. Plant Cell 20, 2848-2859. [PubMed: 18952776]

(46). Rauch B, Pahlke J, Schweiger P, and Deppenmeier U (2010) Characterization of enzymes involved in the central metabolism of Gluconobacter oxydans. Appl. Microbiol. Biotechnol 88, 711-718. [PubMed: 20676631]

(47). Janiak V, Petersen M, Zentgraf M, Klebe G, and Heine A (2010) Structure and substrate docking of a hydroxy(phenyl)pyruvate reductase from the higher plant Coleus blumei Benth. Acta Crystallogr., Sect. D: Biol. Crystallogr 66, 593-603. [PubMed: 20445235]

(48). Domenech J, and Ferrer J (2006) A new D-2-hydroxyacid dehydrogenase with dual coenzymespecificity from Haloferax mediterranei, sequence analysis and heterologous overexpression. Biochim. Biophys. Acta, Gen. Subj 1760, 1667-1674.

(49). Krissinel E, and Henrick K (2007) Inference of macromolecular assemblies from crystalline state. J. Mol. Biol 372, 774-797. [PubMed: 17681537]

(50). Shabalin IG, Filippova EV, Polyakov KM, Sadykhov EG, Safonova TN, Tikhonova TV, Tishkov VI, and Popov VO (2009) Structures of the apo and holo forms of formate dehydrogenase from the bacterium Moraxella sp. C-1: towards understanding the mechanism of the closure of the interdomain cleft. Acta Crystallogr., Sect. D: Biol. Crystallogr 65, 1315-1325. [PubMed: 19966418]

(51). Popov VO, and Lamzin VS (1994) NAD(+)-dependent formate dehydrogenase. Biochem. J 301, 625-643. [PubMed: 8053888]

(52). Cahn JK, Werlang CA, Baumschlager A, Brinkmann-Chen S, Mayo SL, and Arnold FH (2017) A general tool for engineering the NAD/NADP cofactor preference of oxidoreductases. ACS Synth. Biol 6, 326-333. [PubMed: 27648601] 
(53). Boto L (2014) Horizontal gene transfer in the acquisition of novel traits by metazoans. Proc. R. Soc. London, Ser. B 281, 20132450.

(54). Novichkov PS, Kazakov AE, Ravcheev DA, Leyn SA, Kovaleva GY, Sutormin RA, Kazanov MD, Riehl W, Arkin AP, Dubchak I, and Rodionov DA (2013) RegPrecise 3.0-a resource for genome-scale exploration of transcriptional regulation in bacteria. BMC Genomics 14, 745. [PubMed: 24175918]

(55). Ravcheev DA, Khoroshkin MS, Laikova ON, Tsoy OV, Sernova NV, Petrova SA, Rakhmaninova AB, Novichkov PS, Gelfand MS, and Rodionov DA (2014) Comparative genomics and evolution of regulons of the LacI-family transcription factors. Front. Microbioi 5, 294. 


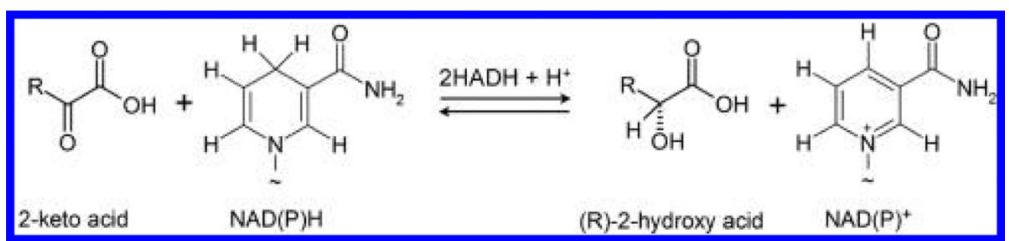

Figure 1.

Reaction catalyzed by D-2-hydroxyacid dehydrogenases. 


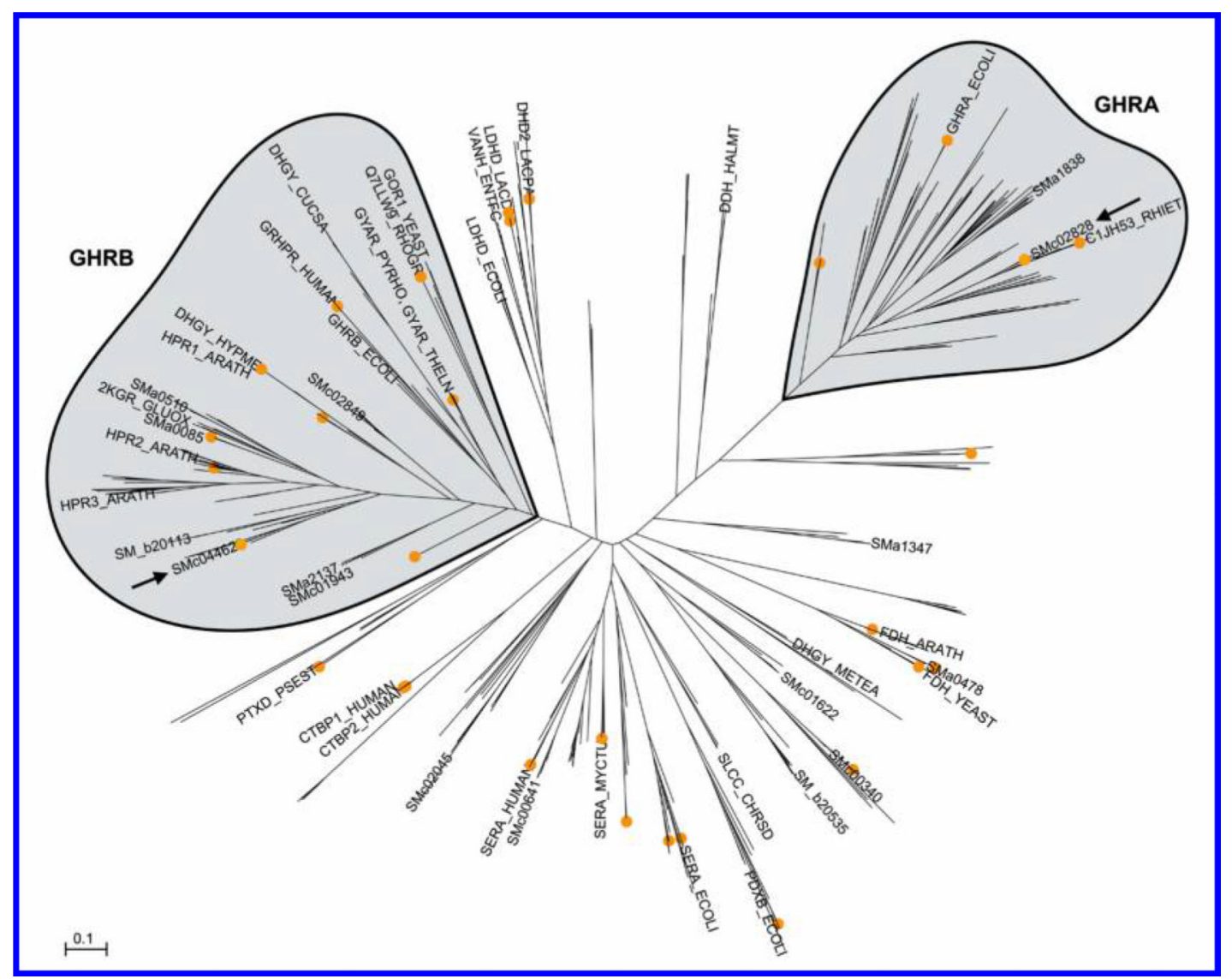

Figure 2.

Maximum-likelihood evolutionary tree of the $2 \mathrm{HADH}$ superfamily. The unrooted tree was constructed with FastTree2, based on multiple alignment of sequences comprising both cofactor-binding and catalytic domains. The branch labels correspond to locus tags of proteins from S. meliloti ("SM" prefix) and UniProt accessions of proteins with studied substrate specificities. Orange dots correspond to proteins with solved crystal structures. Proteins studied in this work, $S m$ GhrA (SMc02828) from the GHRA clade and $S m$ GhrB (SMc04462) from the GHRB clade, are indicated with arrows. Sequence clusters that represent separate enzymatic subgroups are shaded. The scale bar represents the number of estimated changes per position. 


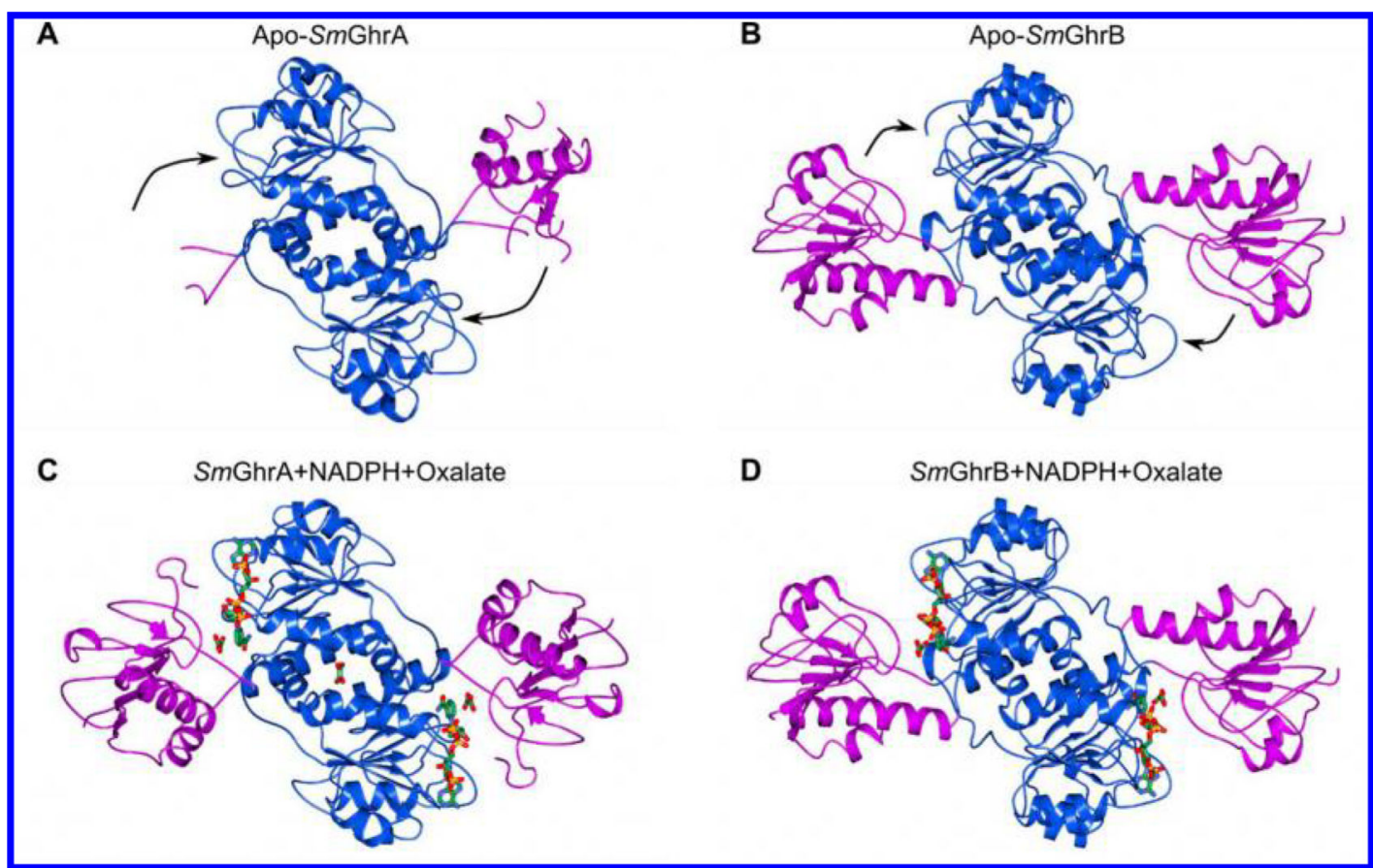

Figure 3.

$S m$ GhrA and $S m$ GhrB: overall structure and catalytic domain movement upon the cofactor binding. (A, B) apo forms of $S m G h r A$ and $S m G h r B$; (C, D) $S m G h r A$ and $S m G h r B$ in complex with NADPH and oxalate. Dimers of $S m G h r A$ and $S m G h r B$ are shown along the twofold intersubunit axis. The coenzyme-binding and catalytic domains are shown in blue and magenta, respectively. The NADPH and oxalate molecules are represented as cylinder models with carbon atoms in green, oxygen in red, and phosphorus in orange. Arrows in the upper panel show the catalytic domain movement upon the cofactor binding. 


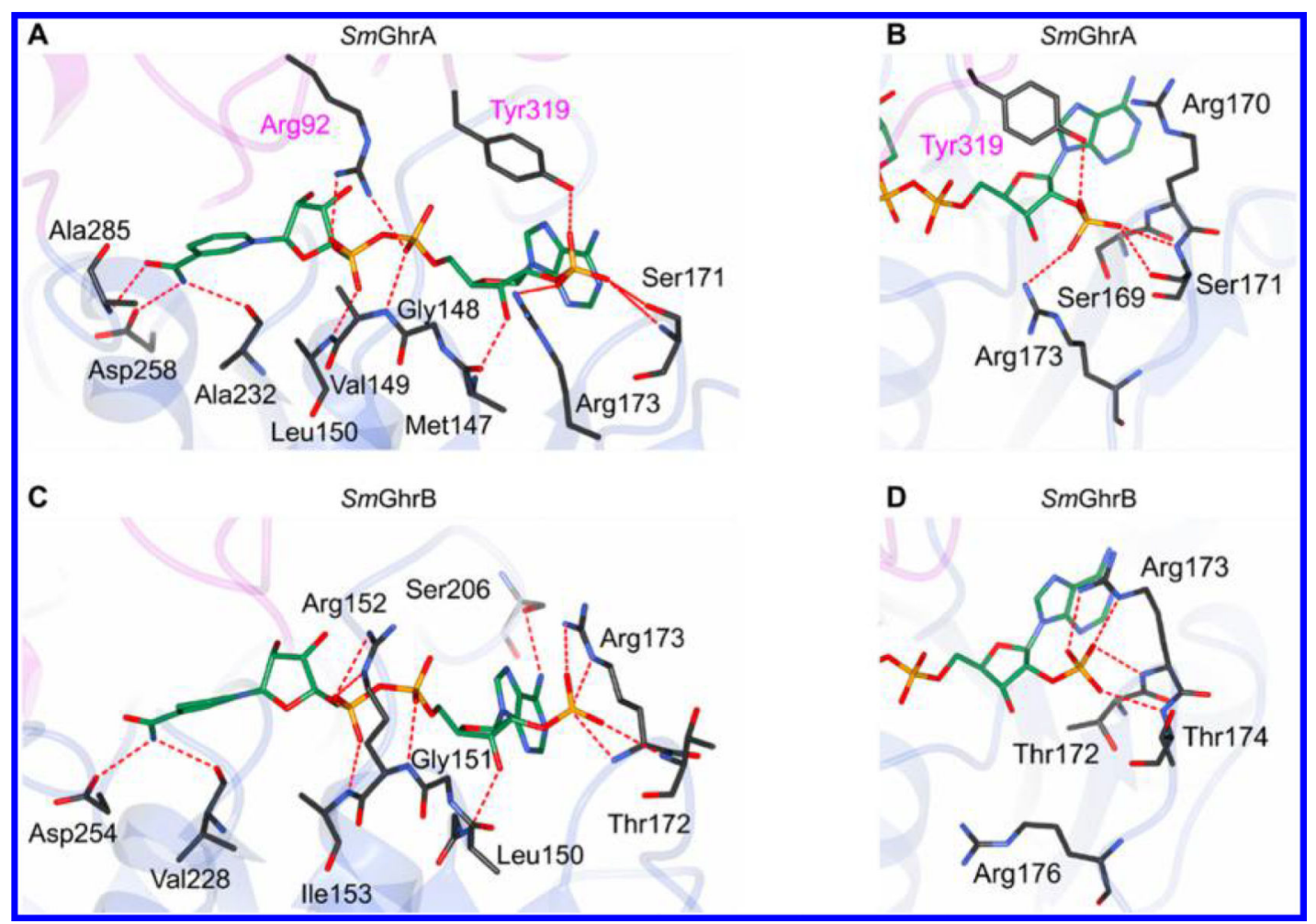

Figure 4.

Comparison of the cofactor-binding environment in $S m G h r A$ and $S m G h r B$. (A, C) Residues forming hydrogen bonds with the cofactor. $(\mathrm{B}, \mathrm{D}) 2^{\prime}$-Phosphate binding site formed by the $\mathrm{S}(\mathrm{T}) \mathrm{RS}(\mathrm{T}) \mathrm{XR}(\mathrm{K})$ motif (nonconserved residue $\mathrm{X}$ is not shown). The cofactor is shown in stick representation; oxygen atoms are depicted in red, carbon in green, nitrogen in blue, and phosphorus in orange. Amino acid residues involved in the cofactor binding by hydrogen bonding are shown in a similar color schema with carbon depicted in gray. Hydrogen bonds are indicated as red dashed lines. Residues from the coenzyme-binding domain are labeled in black, and residues from the catalytic domain are labeled in magenta. 


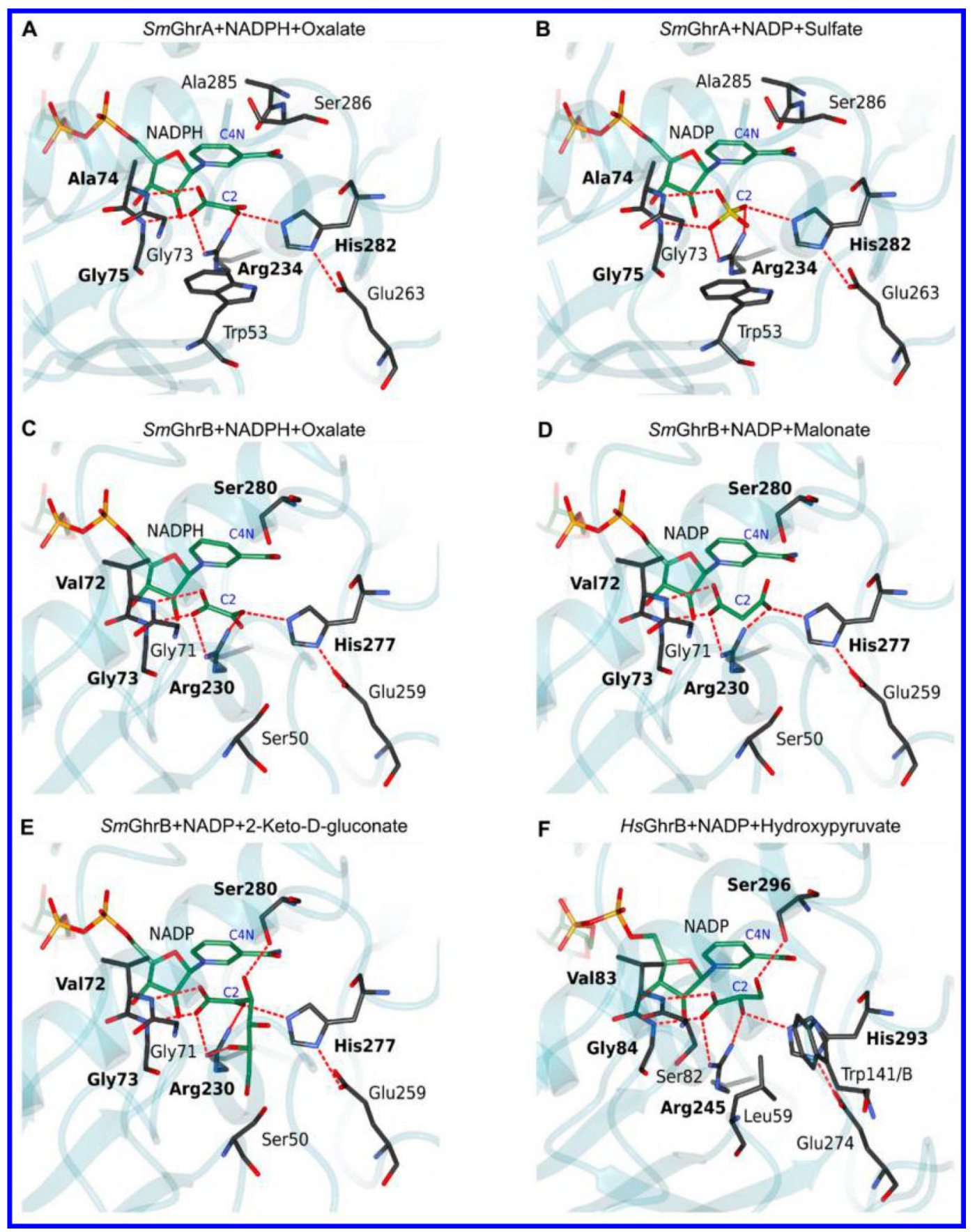

Figure 5.

Comparison of the catalytic sites of ternary complexes. $\operatorname{SmGhrA}(\mathrm{A}, \mathrm{B}), \operatorname{SmGhrB}(\mathrm{C}-\mathrm{E})$, and $H s \mathrm{GhrB}$ (PDB ID: 2gcg) (F). NADP(H), substrates, and substrate analogues are shown in stick representation; oxygen atoms are in red, carbon in green, nitrogen in blue, and phosphorus in orange. The catalytic site residues are shown in a similar fashion with carbon depicted in gray. Hydrogen bonds are indicated as red dashed lines; residues involved in the substrate binding via hydrogen bonds are labeled in bold. C4N atom of NADPH (the donor of the hydride ion) and $\mathrm{C} 2$ atom of substrates or substrate analogues (representing the 
acceptor of the hydride ion) are labeled in blue. The electron density maps, including omit maps, can be inspected interactively using Molstack (http://

molstack.bioreproducibility.org/c/FdBO/). 


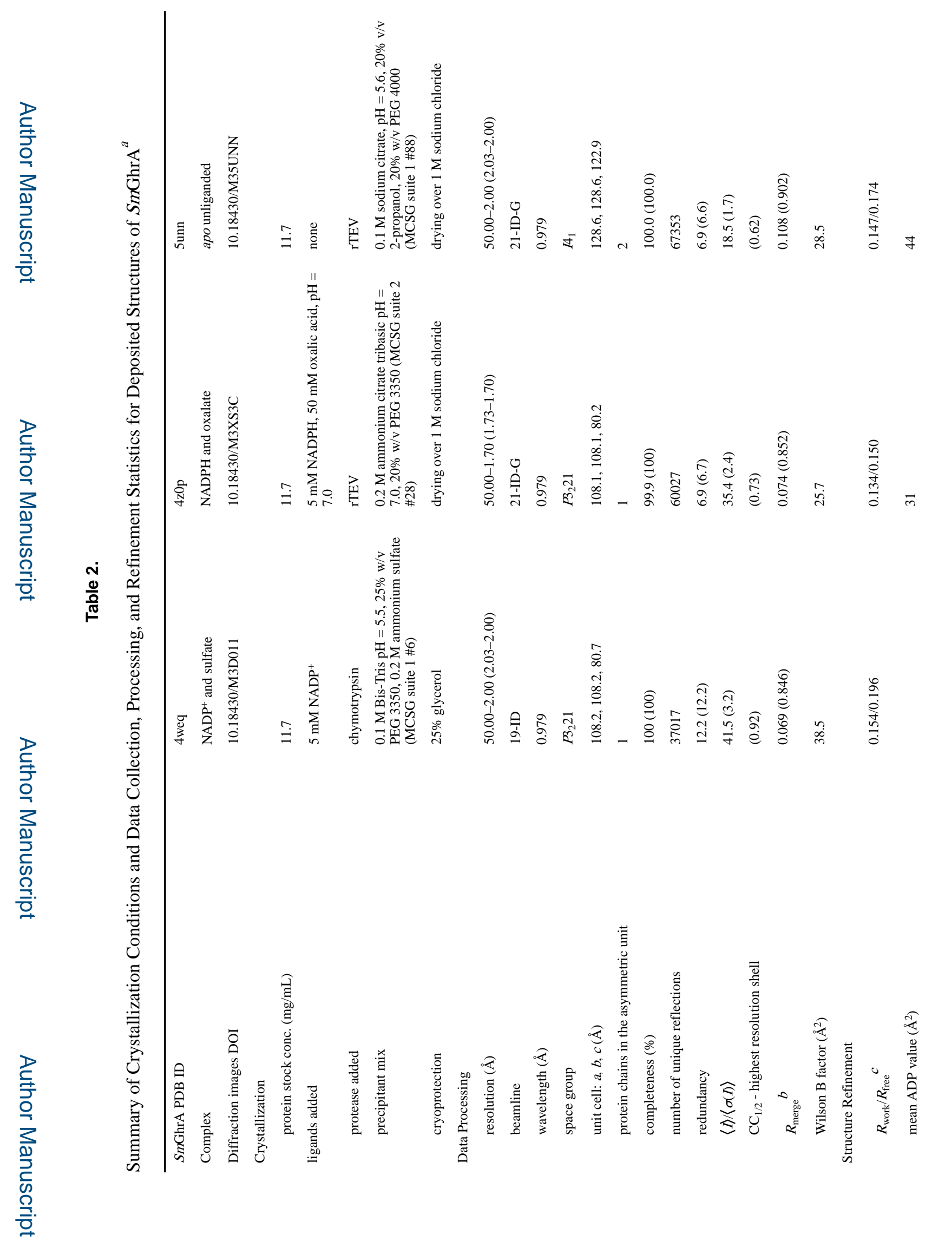

Biochemistry. Author manuscript; available in PMC 2019 April 17. 


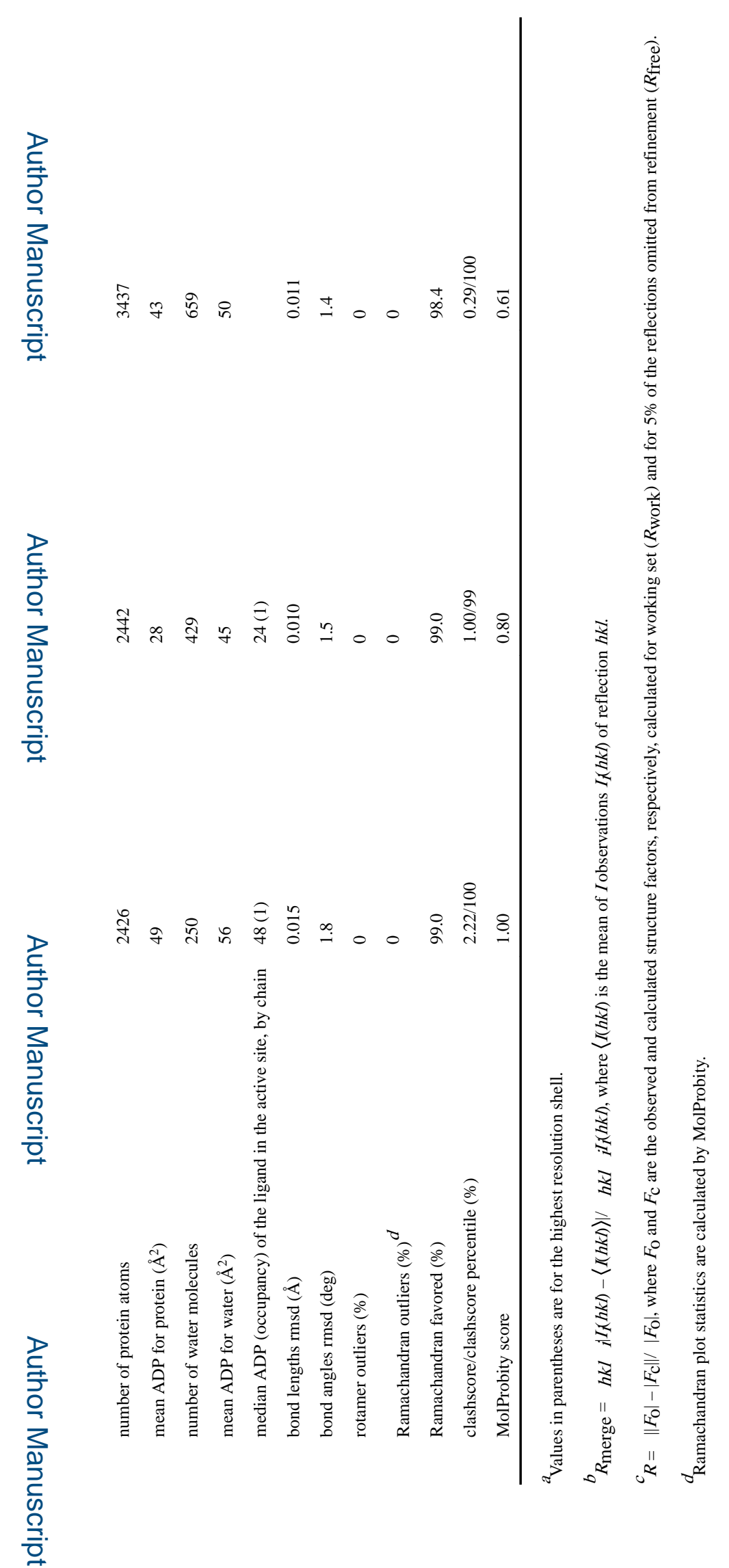

Biochemistry. Author manuscript; available in PMC 2019 April 17. 


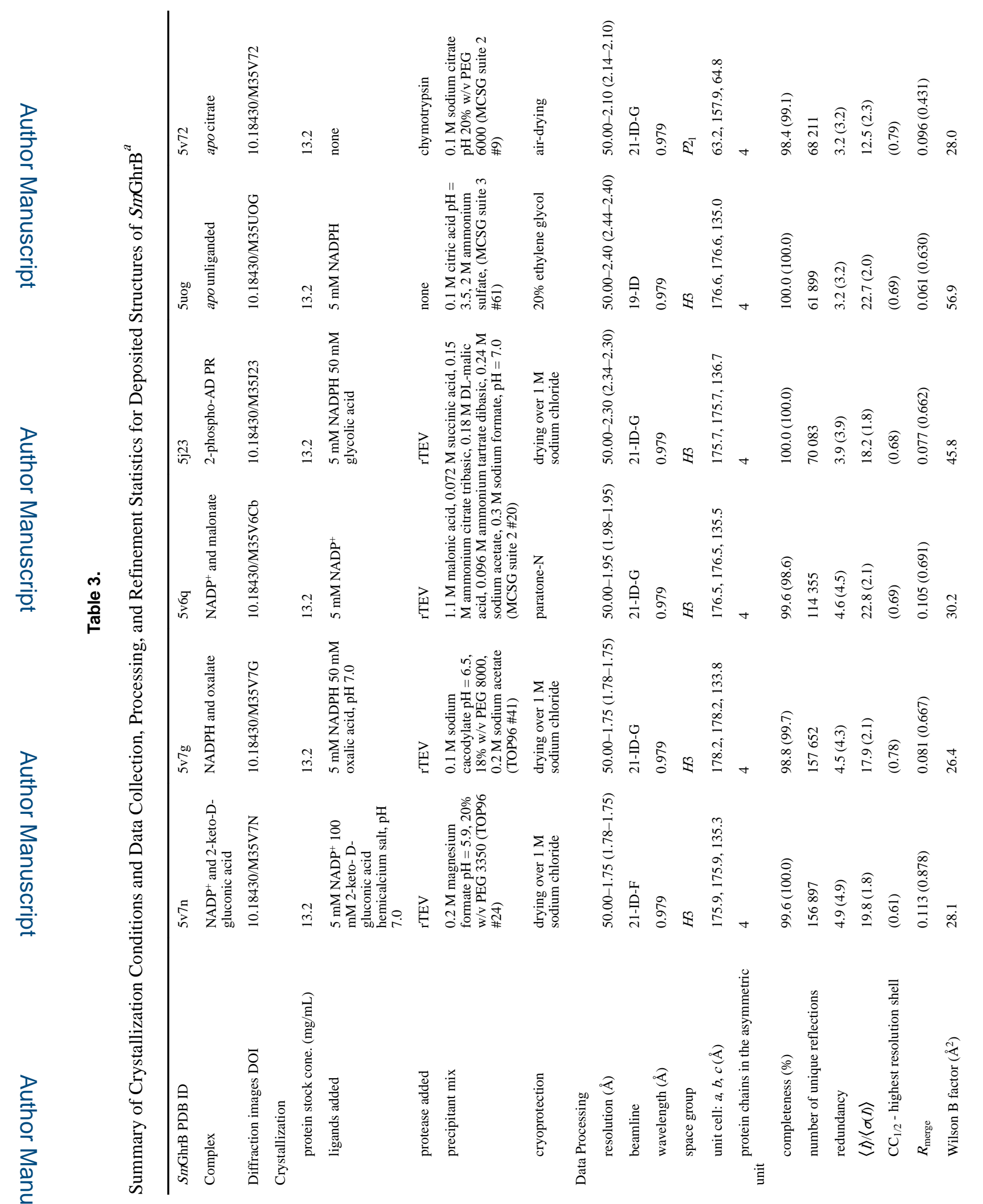

Biochemistry. Author manuscript; available in PMC 2019 April 17. 


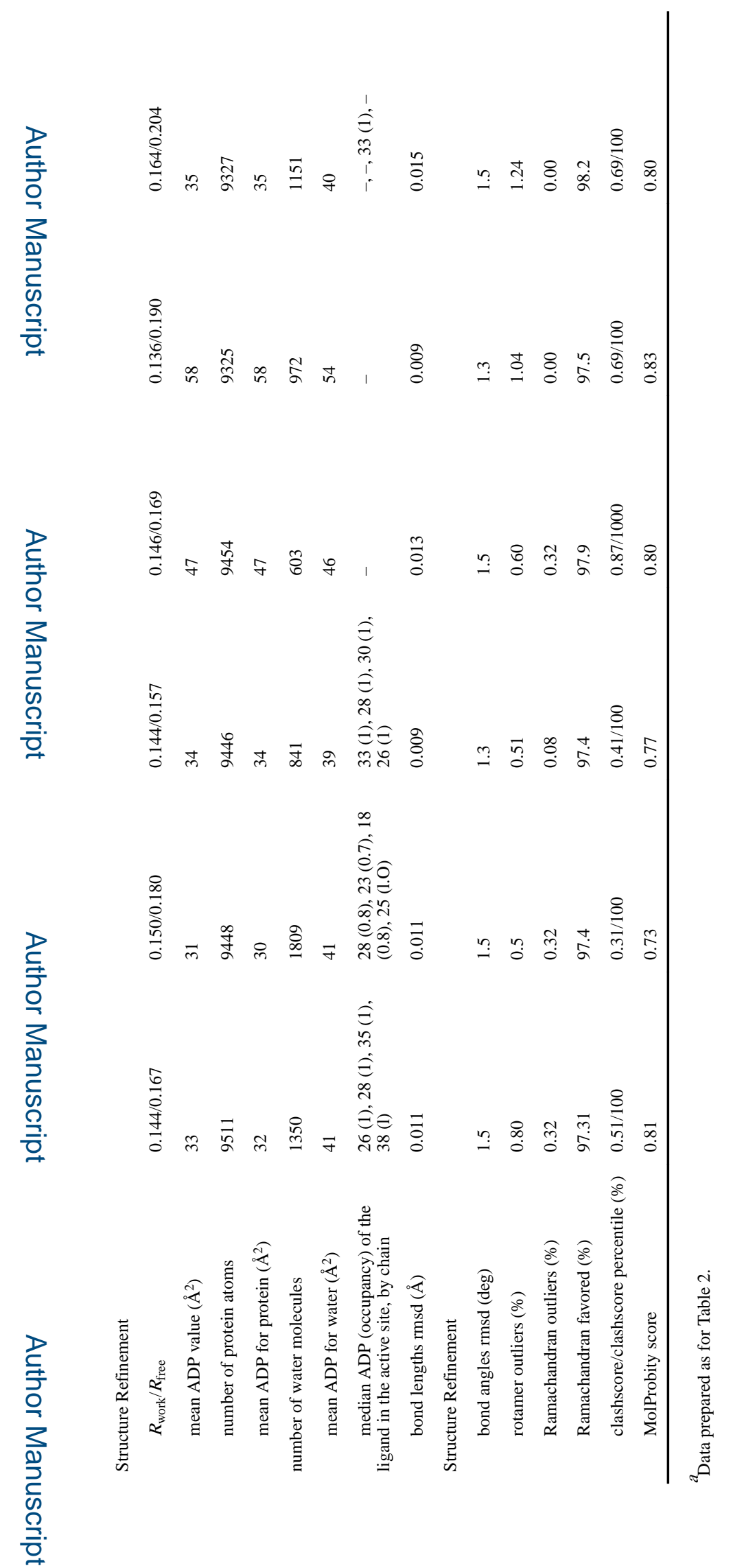

Biochemistry. Author manuscript; available in PMC 2019 April 17. 


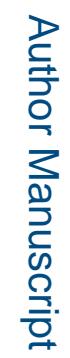

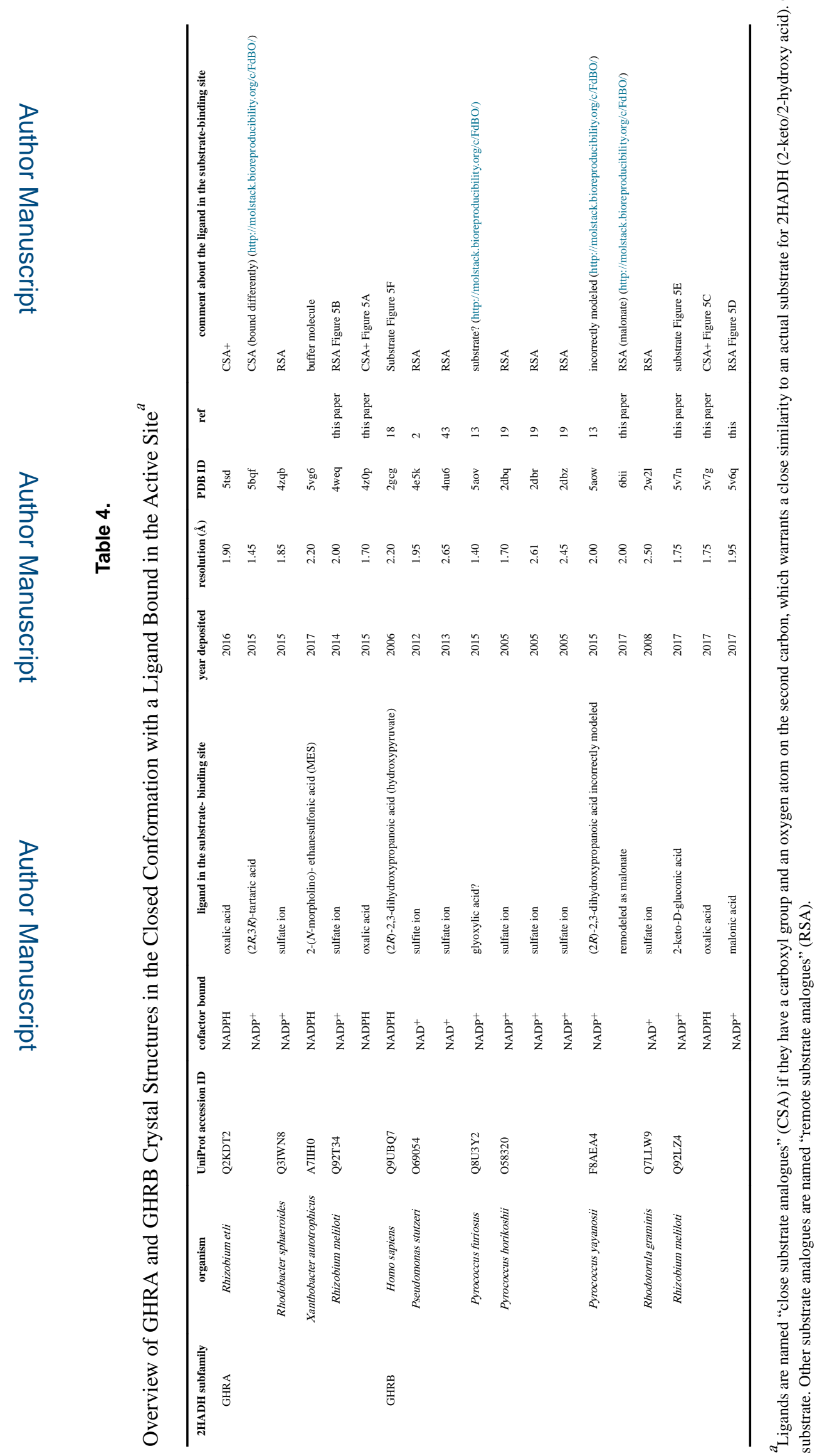

